\title{
Institutional Investors and Foreign Exchange Risk
}

\author{
Timo Korkeamaki and Danielle $\mathrm{Xu}^{*}$
}

December 5, 2010

\begin{abstract}
Financial institutions differ from individual investors both in their analytical ability and in their level of diversification. Their access to derivative markets is also superior compared to that enjoyed by individual investors. All these factors make institutional investors more capable of homemade hedging, and thus lead to an expectation that institutions are drawn to firms with higher foreign exchange risk. Our results support this expectation. We find that after controlling for previously documented determinants of institutional ownership, institutional investors on aggregate are drawn to FX exposure. These findings vary depending on whether the institution type is constrained in its risktaking by the prudent man law.
\end{abstract}

KEYWORDS: institutional investors, foreign exchange risk, homemade hedging

JEL Classification G20, G32

\footnotetext{
Korkeamaki (corresponding author): Hanken School of Economics, Department of Finance and Statistics; and Bank of Finland. E-mail: timo.korkeamaki@hanken.fi, tel. +358 403521 308, fax +358 943133393 Xu: Gonzaga University, School of Business Administration. E-mail:xu@jepson.gonzaga.edu, tel. (509) 313 7030. We wish to thank Reena Aggarwal, Alon Brav, Peter DeMarzo, Erkko Etula, Robin Greenwood, Johan Knif, Juhani Linnainmaa, Tarun Ramadorai, Henri Servaes, Rick Sias, David Thesmar, and seminar participants at the Bank of Finland workshop and the joint seminar of Aalto University and Hanken School of Economics for helpful comments and suggestions. We also appreciate the research assistance of Fredrik Lucander. Financial support from the Academy of Finland is gratefully acknowledged.
} 


\section{Introduction}

With their aggregate holdings at about one half of the U.S. market capitalization, institutional investors and determinants of their portfolio holdings have attracted lively research interest. From recent studies, we know that institutions prefer good corporate governance and effective management (Chung and Zhang, 2009; Parrino, et al., 2003), good quality disclosure (Bushee and Noe, 2000), and large, stable firms with high liquidity (Gompers and Metrick, 2001). They are not as affected by public information releases and firm visibility as individual investors (Grullon, et al., 2004; Barber and Odean, 2008). Even social norms affect institutions' investment decisions (Hong and Kacperczyk, 2009). Some of these determinants tend to vary over time, partly due to institutional herding after various characteristics (Choi and Sias, 2009), and partly due to the explosive growth of institutional holdings themselves (Bennett, et al., 2003). We contribute to this growing literature by exploring institutional investors' appetite for foreign exchange risk.

The idea of homemade hedging refers to the seminal work by Modigliani and Miller (1958), who suggest that investors can themselves hedge those risks of the firm that they are unwilling to carry in their portfolios. For investors to be able to hedge such risks, they need to have knowledge of the firm's risk positions (DeMarzo and Duffie, 1991). Several prior studies (e.g. Geczy, et al., 1997, Bartov and Bodnar, 1994, and Jin and Jorion, 2006) highlight the difficulty for an investor in determining the firm's FX exposure. Financial institutions are likely to possess comparative advantages over individual investors in information acquisition and analysis. With their superior analytical skills, institutional investors should be able to more accurately estimate firms' FX exposure.

Investor-level diversification and risk management ability are important factors in determining whether home-made hedging is feasible (Smith and Stulz, 1985). The homemade hedging argument suggests that all investors share the same risk management abilities, but in practice institutional investors possess a clear advantage over individual investors in this respect. 
Institutional investors tend to be well-diversified, and with their risk-management skills, they can not only consider risk-matching among portfolio assets, but also use of appropriate derivative instruments to adjust the risks of their portfolios when desired. Furthermore, several studies cite scale economies in hedging, as large firms tend hedge more than small firms. Thus, the size of institutional operations, especially in their risk management function should further suggest a negative connection between firm-level risk management and institutional ownership. Equal access to derivative markets is another necessary condition for home-made hedging (Smith and Stulz, 1985). When their excellent access to derivative markets is paired with their analytical abilities, risk management skills, and level of diversification, institutional investors may even enjoy a comparative advantage over the firm in hedging certain risks.

It is also possible that more sophisticated investors prefer more pure risks in their portfolios. Davies, et al. (2010) make such suggestion, and find, in a setting that is very similar to ours, that institutional investors exhibit a preference for pure industry exposures. Assuming that such preference exists, and that institutional investors would view FX exposure as a factor to consider, we would again expect higher institutional ownership to be connected with higher FX exposure.

While the above-mentioned factors may all be necessary conditions for institutions to hold higher levels of FX risk than the rest of the market, they are not alone sufficient to draw institutional investment to firms with high FX risk. We therefore test whether FX risk is a priced factor within our sample, which includes all individual equities held by U.S. financial institutions, as reported in those institutions' $13 \mathrm{f}$ filings. We find a significant difference in both alphas and raw returns between high and low FX exposure stocks. This is an interesting finding, and new to the literature, as previous studies report evidence of FX exposure being priced only at the aggregate market level and in the industry portfolios (see e.g. DeSantis and Gerard, 1998, and Francis, et al., 2008, respectively). The expected risk premium on FX-risk provides institutional investors with a profit incentive to seek FX-risk. 
Institutional investors are fiduciaries, and thus face limitations in their risk positions. In the early part of our sample, this is particularly applicable to institutions governed by the prudent man rule, which focused on the asset-specific risk, rather than risk in portfolio setting (Del Guercio, 1996). Therefore, institutions governed by the rule may have avoided high FX exposure stocks, even if such stock might have reduced the overall riskiness of their portfolio. The evidence reported by Parrino, et al. (2003) supports the effect of the prudent man laws, as they report a reduction in bank trust holdings attributable to volatility increases. Since the latter part of the 1990s, a transformation from the prudent man rule towards regulation that focuses on risk in a portfolio context has taken place (Schanzenbach and Sitkoff, 2007; Hankins, et al., 2008). Today, most states have adopted the Prudent Investor Act, or a similar regulation. ${ }^{1}$ This regulatory shift should reduce the avoidance of extreme FX exposures among institutions that were previously affected by the prudent man rule.

We measure the exposure of U.S. firms to a trade-weighted foreign exchange index, and then observe the connection between FX exposure and holdings of different types of financial institutions. We expect institutions in general to favor firms with higher FX exposures. Furthermore, we expect this effect to be concentrated in institution types that are less bound by prudent-man laws.

Our results are consistent with our expectations. After controlling for other determinants of institutional ownership suggested by prior studies, we find that at the aggregate level, institutional investors have higher holdings in stocks with more FX exposure. Among different types of financial institutions, we find that bank trust departments' holdings are lower in firms with high FX exposures, which supports the notion that the prudent man rule affects institutions' portfolio

\footnotetext{
${ }^{1}$ Schanzenbach and Sitkoff (2007) report that in August, 2005, Mississippi was the only remaining state that had adopted neither the Uniform Prudent Investor Act, nor a similar statute that relies on the portfolio setting in determining prudence of a portfolio managers. They also show that Washington was the earliest adopter of such rules, in 1995.
} 
construction. Investment firms and independent investment advisors exhibit a preference for high FX exposure stocks. These results are robust to controlling for other determinants of institutional ownership, suggested by prior studies. They thus support the notion that FX risk is a factor in considering prudence from the legal point of view. Similar to Bennett, et al. (2003), we find institutions' preferences to vary over time. In particular, we find that the preference for less FX exposure among bank trusts has weakened over time. This finding is consistent with an earlier observed shift in investment behavior of bank trusts, related to dividends (Hankins, et al., 2008), and stock holdings in general (Schanzenbach and Sitkoff, 2007).

Our finding of a positive connection between FX exposure and institutional ownership contradicts studies within hedging literature that report that firms with high institutional ownership tend to use more financial hedging instruments (e.g. Geczy, et al., 1997; Graham and Rogers, 2002). This apparent conflict is likely to be due to our use of realized stock exposures rather than disclosure information on derivatives usage, as the stock exposures capture both financial and operational hedging ${ }^{2}$. Use of stock return exposures also allows us to have a large sample size, both cross-sectionally and through time. It should also be noted that when all institution types are considered as an aggregate measure of institutional ownership, our evidence of a positive connection between institutional ownership and FX exposure is much stronger in the more recent sub-samples. ${ }^{3}$

\footnotetext{
${ }^{2}$ Guay and Kothari (2003) argue that observation of derivatives use may give an imperfect picture of the firm's risk management practices. Along with Smith and Stulz (1985), and more recently Bartram, et al. (2010), they suggest that operational hedges such as matching the structure of firm assets and liabilities may play a more significant role than derivatives in corporate risk management. Petersen and Thiagarajan (2000) provide evidence of natural and derivativebased hedges resulting in similar exposures, and Jin and Jorion (2006) report on regression methods' ability to capture risk management activities of the firm.

${ }^{3}$ Graham and Rogers (2002) study derivatives usage in 1994-1995, and Geczy, et al. (1997) study the fiscal year end of 1991.
} 
Causality of our reported relation between institutional ownership and FX exposure deserves special attention. While we consider FX exposure as a feature attracting institutional ownership, many of the papers cited above suggest reverse causality, as they propose a role for the presence of institutional ownership in the corporate hedging behavior. We make several efforts to establish the direction of causality of our findings. First, we document that among different institutional investment styles suggested and compiled by Bushee (1998), the connection between FX exposure and institutional ownership is less pronounced among institutions with investment styles that are more prone to activism. Second, we fail to find a connection between concentration of institutional investments in a firm and the firm's FX exposure, which suggests that institutions are not using the decision power gained by increased ownership to affect firms' hedging decions. Finally, following Brav, et al. (2008), we study the 13d filings that institutions file in connection with block purchases, and find that they extremely rarely indicate a concern for risk management or FX exposure among motivations for the purchase. The suggestion that causality runs from firm characteristics to institutional investment and not vice versa is supported by several studies that report that institutions are more likely to vote with their feet, rather than resort to activism (e.g. Grinstein and Michaely, 2005; and Parrino, et al., 2003).

The rest of the paper is organized as follows. Section 2 describes data that we use, section 3 presents the results on institutional holdings by FX exposure quintiles, section 4 considers the role of FX exposure as a new additional determinant of institutional holdings. Finally, section 5 concludes.

\section{Data}

We consider the connection between institutional ownership and FX-exposure during the period of 1980-2007. Our data come from three main sources. In estimation of firm-specific FXexposures and measures related to volatility and market risk, we use the monthly returns from the 
Center of Research in Security Prices (CRSP). We collect data on institutional ownership from Thomson Financial (formerly known as CDA Spectrum). The Thomson Financial database classifies institutions to five categories, bank trust departments, insurance companies, investment companies, independent investment advisors, and others (the last category includes pension funds, endowments, and miscellaneous institution types). Thomson acknowledges that subsequent to 1998, institution types reported in the database are unreliable. We therefore use corrected and verified institution type codes from Brian Bushee to classify institution types. ${ }^{4}$ We also use his refined classification, as he segregates the "others" category in the Thomson database to pension funds and miscellaneous groups. Finally, our control variables that are based on accounting data come from Compustat.

\section{TABLE 1}

Table 1 summarizes our data on institutional ownership by year. We report both aggregate institutional ownership, and ownership by institution types. Fast growth of the sector is evident from Table 1 . The firm-level average institutional holdings have increased from $17 \%$ to $47 \%$. Over our sample period, the relative holdings of bank trusts, insurance companies, and pension funds have been stable, whereas a significant increase in investment, and independent investment advisors (IIA) categories is evident. The latter two categories capture mutual funds and hedge funds, respectively. ${ }^{5}$

\footnotetext{
${ }^{4}$ The data is captured from http://accounting.wharton.upenn.edu/faculty/bushee/IIclass.html. We thank Brian Bushee for providing this information.

${ }^{5}$ Due to somewhat unclear definitional differences between investment firms and independent investment advisors, Hong and Kacperczyk (2009) combine the two groups. We hold them separate in order to observe any potential differences in the behavior of the two groups.
} 
The Thomson database of U.S. institutional holdings fails to capture U.S. holdings by foreign institutions. Ferreira and Matos (2008) report that in 2005, foreign institutions stood for about 9\% of the total institutional investment in the U.S. stock market. Since our main purpose is to measure the institutional demand for stocks with different levels of FX exposure, the presence of foreign institutions should not affect the inferences that our data yield. Our research design builds upon institutions and individual investors having different abilities to analyze and manage FX risk. Even in the unlikely case that foreign institutions' holdings are negatively correlated with U.S. institutions' holdings, the presence of sophisticated and diversified investors in our noninstitutional group would only bias us against finding a positive relationship between institutional holdings and FX exposure.

\section{Results}

We begin our empirical analysis by segregating the firms in the CRSP database into quintiles based on the size of the FX-risk coefficient. In estimating FX exposure, we augment the threefactor model proposed by Fama and French (1992), as shown in equation (1).

$$
R_{i, t}=\alpha_{i}+\beta_{m k t, i} R_{m k t, t}+\beta_{F X, i} R_{F X, t}+\beta_{S M B, i} R_{S M B, t}+\beta_{H M L, i} R_{H M L, t}+\varepsilon_{i, t}
$$

Following Jorion (1990) and many others, we define FX-exposure as the $\beta_{\mathrm{FX}, \mathrm{i}}$ - coefficient in equation (1). While we use it as the main proxy for FX-risk in the remainder of the paper, our results are very similar if we use either the basic CAPM without the Fama-French style factors, or an augmented four-factor model that includes the Carhart (1997) momentum factor. As our main proxy for FX fluctuation $\left(\mathrm{R}_{\mathrm{FX}}\right)$, we employ the broad U.S. Trade-weighted exchange rate index, with data coming from the Federal Reserve Bank of St.Louis. We discuss the use of alternative FX 
fluctuation proxies later in Section 3.4. Our market portfolio $\left(\mathrm{R}_{\mathrm{mkt}}\right)$ is the CRSP value-weighted market index. The factor returns for the Fama-French factors come from Kenneth French's website.

Each year from 1983 to 2007, we estimate the augmented 3-factor model in equation (1), using each firm's monthly returns over the past three years. ${ }^{6}$ We then rank the firms based on the estimated FX-exposure coefficients, and form quintile portfolios. Figure 1 shows that the average FX-exposure varies significantly across the quintiles. The distribution appears fairly symmetric, as the extreme quintiles are approximately equally apart from zero. The middle quintile has the average FX exposure close to zero. Lack of a monotonic time trend in the extent of FX exposure reduces the concern that the relation between institutional ownership and FX exposure would be due to a shared time trend between the two variables.

\section{FIGURE 1}

\subsection{Pricing of FX exposure}

We make arguments in this paper for institutional investor's ability to more readily hold stocks with high FX exposure. However, without proper incentives, institutions may not use their skill and ability to manage FX exposure. In this sub-section, we explore pricing of FX exposure, as an expected risk premium on the exposure would provide institutions with an incentive to carry it.

Prior studies indicate that FX risk is priced in the US at the aggregate level (DeSantis and Gerard, 1998; Carrieri, et al., 2006) and at the industry level (Francis, et al., 2008). However, evidence of pricing of FX exposure at the firm level is lacking. Following recent asset pricing literature (see e.g. Pastor and Stambaugh, 2003), we perform a test of FX exposure at the firm level by observing returns in quintiles that are sorted by FX exposure. The results are reported in Table 2.

\section{TABLE 2}

\footnotetext{
${ }^{6}$ A minimum of 12-monthly observations is required for a firm to be included.
} 
Each month, we rank and form quintile portfolios based on firms' FX exposures using the past 12 monthly returns. ${ }^{7}$ We report value-weighted portfolio alphas and raw returns in Table 2. The FX exposures are estimated with the CAPM, the 3-factor, and the 4-factor model, respectively. Regardless of the model we use to calculate the FX exposures in the sorting phase, all three models indicate that alphas for the high FX exposure quintile are significantly higher than those for the low exposure quintile. The raw portfolio returns exhibit a similar pattern. Besides being statistically significant, the effect appears to be also economically significant, as our estimate for the difference in alphas between the extreme quintiles varies from $0.57 \%$ to $1.06 \%$ per month, and the raw return difference is about $1 \%$ per month. The finding is interesting given the lack of evidence of a FX exposure premium at the firm level. Given that the marginal investor for many of our sample firms should be an institutional investor with an ability to diversify FX risk, the observed premium is surprisingly large. Presence of the premium provides an incentive for institutional investors to use their ability to manage FX exposure.

\subsection{FX exposure management within institutional portfolios}

If institutional investors consider FX exposure as a risk factor, then they could manage this risk by carrying stocks with opposite exposures in their portfolios. In this section, we study whether institutions with a heavy weight in stocks with a negative exposure would also have higher weights in positive exposure stocks. The results are reported in Table 3.

\section{TABLE 3}

\footnotetext{
${ }^{7}$ Ang, et al. (2009) argue for use of contemporaneous sorts. In our case, contemporaneous sorts yield inferences that are practically identical to those reported in Table 2.
} 
The portfolios in Table 3 are sorted based on the average negative FX exposure of each institutional portfolio. The table shows both average negative and positive exposures of each quintile, where all positive exposure stocks and negative exposure stocks are considered separately. In other words, the top row for high exposure reports the average negative exposure of all stocks with negative exposures, and the average positive exposure of all stocks with positive exposures, where the average negative exposure has been used to sort the portfolios. While the negative exposures naturally increase significantly across quintiles, as the quintiles are based on the negative exposures, the positive exposures exhibit a very similar pattern. The results in Table 3 can be viewed as evidence of matching positive and negative exposures taking place within institutional portfolios. Thus, our suggestion that institutions manage FX risk within their investment portfolios receives support.

When we calculate a Herfindahl index to measure the level of diversification for each institutional portfolio, we get seemingly odd results that at the aggregate, higher portfolio concentration is connected with lower absolute FX exposure (results not reported). However, this finding can be reconciled by looking at Table 3. More diversified portfolios can indeed have higher FX exposure, especially when that exposure is measured as the average absolute value of the FX exposure coefficien in equation (1). Obviously, FX risk can be managed both within portfolio, and with derivatives. Besides the diversification story discussed above, the finding that more diversified portfolios exhibit higher FX exposure could imply that those institutions either use derivatives to manage their FX exposure, or alternatively that they knowingly take one-sided risks regarding foreign currencies.

\subsection{Institutional holdings by FX exposure quintiles}

We take a first look at the relation between the FX-exposures and institutional holdings in Table 4. Panel A of Table 4 reports institutional holdings in FX-risk quintiles, with each column 
indicating a different institution type. The average $\beta_{\mathrm{FX}, \mathrm{i}}-$ coefficient for each quintile is reported in the last column. The aggregate institutional holdings are somewhat tilted towards firms whose stock returns exhibit a positive correlation with FX changes. Among institution types, bank trust holdings are higher in the mid-quintiles, as banks seem to shy away from both positive and negative extreme values, i.e. firms with high sensitivity to FX fluctuation. This is consistent with our expectations, as bank trusts are viewed in prior literature as the most prudent institution type. In contrast, holdings of investment, independent investment advisor (IIA), and miscellaneous categories appear to be tilted towards the extreme FX exposure quintiles.

\section{TABLE 4}

In Panel B of Table 4, the quintile sorting is based on the absolute value of the $\beta_{\mathrm{FX}, \mathrm{i}}-$ coefficient, which, as a monotonic measure, lends itself better to observation of institutions' risk preferences. By using the absolute value, we make an implicit assumption that foreign exposure is symmetric, and that positive and negative exposures affect firms similarly. We thus assume that a hypothetical importer and exporter face equal FX risk, as both the extent, and even the direction of FX fluctuations is difficult to predict in the short run. This is an issue that has received lively research interest. While some authors find asymmetric empirical patterns in firms' FX exposures ${ }^{8}$, others offer support for symmetry. ${ }^{9}$ As mentioned, we use the absolute FX exposure as our main measure of interest in the rest of the paper. However, our regression results that are reported in section 4 are practically identical if we analyze positive exposures and negative exposures in separate sets of regressions. In Panel B, we report the difference in average holdings between the two extreme quintiles, along with t-statistics for the difference. Interestingly, the three institution

\footnotetext{
${ }^{8}$ See e.g. Koutmos and Martin (2003) for empirical evidence, or Bartram, et al. (2010) for theoretical motivations for asymmetry in FX exposure

${ }^{9}$ E.g. Choi and Prasad (1995).
} 
categories that are most constrained by the prudent man rule, namely banks, insurance, and pension funds ${ }^{10}$, all show a statistically significant preference for the lowest FX exposure quintile over the highest FX exposure quintile, whereas the independent advisor category exhibits a preference for the high FX exposure quintile. It is worth noting that the effect does not appear to be linear across quintiles. The statistical significance seems to be driven mostly by avoidance of the highest exposure quintile by bank trust, insurance companies, and pension funds, and by independent advisors avoiding the lowest exposure quintile.

\subsection{Alternative foreign exchange proxies and the effect of foreign firms}

The U.S. trade patterns have changed dramatically during our sample period. For example, the weight of China in the broad trade-weighted currency index that we use has changed from $1.3 \%$ in 1980 to $17.3 \%$ in 2007 (Federal Reserve, 2010). The increased weight on China and other emerging markets could affect not only the patterns in FX exposure, but also firms' ability to manage their FX risk (Francis, et al., 2008). While the evidence we report in Figure 1 reduces this concern, as the magnitude of FX exposure in our exposure quintiles has remained relatively stable throughout our sample period, we address this concern further by employing alternative FX indices. The use of alternative trade-weighted indices on "Major currencies" and "Other important trading partners" (from the Federal Reserve Bank of St.Louis) yields results that are practically identical to those that we report in this paper (results not reported). ${ }^{11}$ It should also be noted that our use of trade-weighted indices is likely to bias our observed exposures downward. Dominquez and Tesar

\footnotetext{
${ }^{10}$ See Del Guercio (1996), Badrinath, et al. (1996), and Brav and Heaton (1998) for evidence and motivations on why these types of institutional investors are more restricted due to the prudent man regulation.

${ }^{11}$ As of 2010, the "Other important trading partners" group includes Mexico, China, Taiwan, Korea, Singapore, Hong Kong, Malaysia, Brazil, Thailand, Philippines, Indonesia, India, Israel, Saudi Arabia, Russia, Argentina, Venezuela, Chile and Colombia.
} 
(2001) show that since individual firms tend to be exposed to certain individual currencies, use of an index may lead to underestimation of true exposures at the firm level.

As our sample contains the CRSP universe, it includes foreign firms with ADR listings in the U.S. While our prediction is that U.S. institutions are equally drawn to FX exposure regardless of the home country of the firm, we rerun our tests without the ADR firms. Our results (not reported) suggest that ADR firms have no marked effect on our reported findings.

\subsection{The connection between commodity risk and foreign exchange risk}

Recent evidence by Chen, et al. (2010) suggests that commodity prices are an exchange rate fundamental, especially in countries with high commodity output. Therefore, foreign exchange changes are related to commodity fluctuations. Also, firms in mining and oil industries deviate from the rest of the firms as their output tends to be priced in dollars even when it is exported (Jorion, 1990). We address the special role of commodities and commodity-related industries first by adding a term for the S\&P GSCI Commodity Index to equation (1) and thus estimating FX exposures while controlling for commodity fluctuations. Similar to our reported results, bank trusts avoid FX exposure even in that setting, and investment and independent advisor categories are drawn to it (results not reported). Second, we test the robustness of our reported results to exclusion of oil industry firms from our sample. Those tests yield inferences that are very similar to those reported in the paper.

\subsection{Variation by institution size}

Institutional risk preferences may vary by institution size. Smaller institutions could be less diversified, and therefore less capable of carrying assets with high exposure. While we consider diversification issues above in section 3.2, in this section, we discuss other potential factors that make small institutions differ from their large counterparts. Most importantly, smaller institutions 
might lack resources in analyzing a multitude of factors, and thus they would specialize in assets with certain features (Van Nieuwerburgh and Veldkamp, 2010). This issue is related to the argument about economies of scale in hedging, discussed in the introduction. Davies, et al. (2010) consider small and large institutions separately, and find that small institutions exhibit a stronger preference for industry exposure. They attribute their finding mostly to an asset substitution hypothesis, by which investors invest in stocks as a substitute for investing in the underlying factor. Asset substitution is feasible for industry exposure, but less so for FX exposure, as taking positions directly (either long or short) in most currencies should not be a difficult task for a financial institution of any size.

We compare institutional holdings in different FX exposure quintiles separately for large and small institutions by dividing our sample into above median and below median sub-samples at the end of each year. The division is based on the total market value of the equity portfolio, both for aggregate institutional holdings and for each institution category separately. We find that our main results are robust across size categories, as among both large and small institutions, bank trusts tend to avoid FX exposure, and investment and IIA categories are drawn to it. However, consistent with Davies, et al. (2010), the difference in holdings between the highest and the lowest exposure quintiles is statistically more significant among small institutions (results not reported).

\section{Regression evidence of FX exposure as a determinant of institutional ownership}

Next, we turn to regression analysis to evaluate the effect of FX risk on holdings of different types of financial institutions. The regression setting allows us to control for other firm characteristics affecting institutional holdings, as suggested by prior literature. We run separate regressions for each institution type, with holdings by each institution type serving as the dependent variable. Our test variable is the FX exposure, which is represented by the absolute value of the $\beta_{\mathrm{FX}, \mathrm{i}}-$ coefficient defined in equation (1). As mentioned above, our results are practically identical 
if we use the CAPM, or the Carhart (1997) four-factor model to control for market-wide risks instead. In each specification, we use three years of monthly data to estimate the FX-coefficient. Our control variables are motivated by prior literature on institutional ownership. SIZE is the natural logarithm of the market capitalization of equity. Controlling for firm size is motivated by the Gompers and Metrick (2001) finding that institutional investors tend to invest in larger firms. They also discuss the role of book-to-market ratio in indicating patterns in both risk and past return, potentially attracting institutional investors. Our $\log (\mathrm{b} / \mathrm{m})$ variable is defined as the natural logarithm of the ratio of the book value of equity to the market capitalization of equity. Gompers and Metrick (2001) further find that institutions tend to invest in firms with low past performance. Our $R E T_{-12,0}$ (stock return in the 12 months preceding the observation year-end) controls for the effect of past firm performance on institutional holdings. Gompers and Metrick (2001) and several subsequent papers also include the firm's stock price as a determinant for institutional holdings. The variable is motivated as a proxy for liquidity. We use the inverse of the firm's stock price at the end of the year (1/Price) to control for the effect of stock price on institutional ownership. DelGuercio (1996) and Brav and Heaton (1998) suggest that higher dividend yields are connected with more prudent investments, which could entice higher holdings for institutions bound by the prudent man rule. Grinstein and Michaely (2005) offer support for the idea. DIVYLD is the annual dividend over the year-end stock price. Finally, like DelGuercio (1996), we include a dummy variable for firms that are included in the S\&P 500 Index. The variable is set to capture the certification effect of S\&P 500 membership. We also include industry dummies in each specification to capture any industry-specific demand patterns in institutional ownership. We exclude a couple of control variables that are commonly used in studies exploring determinants of institutional ownership, namely stock return standard deviation and market beta. While most papers find a positive connection between institutional ownership and volatility, the evidence in Sias (1996) strongly suggests that institutional ownership causes volatility, and not vice versa. We thus 
exclude it from our reported regressions for endogeneity concerns. We note, however, that despite the potential endogeneity problems, our main findings are robust to its inclusion. The market beta of the stock is already controlled for in the first stage of our estimation, in equation (1).

\section{TABLE 5}

In Table 5, we report results of pooled OLS. The coefficients of the FX exposure variable are consistent with our expectations. With aggregate institutional holdings as the dependent variable in the first column, the FX exposure enters with a positive and significant sign, indicating that institutions are drawn to firms with more exposure. When different institution types are observed separately in the subsequent columns, the institution type most often cited for prudence, namely bank trusts, indicates a dislike for FX exposure, whereas investment and independent investment advisor categories exhibit a positive connection between their holdings and FX exposure. Most of our control variables are highly statistically significant, and enter with signs that are consistent with prior literature. It is interesting to note that our model's explanatory power is fairly constant across different types of institutions, except for the insurance industry and the miscellaneous category. The difficulties in explaining institutional holdings in the insurance industry are consistent with Badrinath, et al. (1996) notion that in the insurance industry the aggregate investment portfolios may include several sub-portfolios that represent e.g. different insurance lines, with varying risk and return characteristics.

The panel nature of our data set is bound to cause cross-sectional correlation in our variables. For that reason, it is common in this type of studies to use Fama-MacBeth regressions to estimate a connection between the estimated risk exposure and firm variables. We follow this method in regressions reported in Table 6. Our cross-sectional Fama-MacBeth regressions are set up such that for each year from 1983 to 2008, we regress the cross-section of institutional ownership on each 
firm's FX exposure and average firm characteristics over the past three years. In Table 6, we report the time-series average coefficients. The t-statistics are calculated using the Newey and West (1987) procedure with two lags.

\section{TABLE 6}

While some minor variation can be observed between Tables 5 and 6, our main findings are intact. Namely, bank trusts tend to dislike FX exposure and investment firms and independent investment advisors exhibit a preference for FX exposure. In the Fama-MacBeth setting, we are unable to use year dummies, which could explain some of the differences between Tables 5 and 6 .

If FX exposure affects institutional investment decisions, then we should also expect individual institutions' holdings patterns with respect to FX exposure to exhibit persistency over time, so that institutions with high FX exposure would constantly invest in firms with high FX exposure, and vice versa. We explore this issue by observing the FX exposure of institution-level portfolios through time. We estimate the portfolio FX exposure for each institution by first calculating the weighted average of exposure of their portfolio holdings at the end of each quarter, and then taking the average of these averages each year, to represent that year's average FX exposure of their portfolios. Correlation between institutions' average FX exposure and its one-year lag is .6475, which speaks for persistency in institutions' FX exposure. When we regress the average FX exposures on lagged FX exposures and firm-level control variables, ${ }^{12}$ we find overwhelming support for a connection between FX exposures and their lagged values for all institution types (results not reported).

\footnotetext{
${ }^{12}$ Our control variables are suggested by the hedging literature as determinants of firm's FX exposure, and include $\log$ (assets), $\log ($ book/market), $\log$ (foreign sales \%), $\log (\mathrm{R} \& \mathrm{D})$, capex/sales, $\log (\mathrm{ROA})$, and leverage. They are also averaged for the holdings of each institution.
} 


\subsection{Errors-in-variables}

Since the FX-exposure coefficient is estimated from equation (1), it is measured with error. This raises concern for the errors-in-variables problem in the regression results that we report (Shanken, 1992). As measurement errors may lead to correlation between the estimated coefficients and the error term, which will further cause the OLS estimator to be inconsistent, we next employ the generalized method of moments (GMM) to mitigate these issues. The system of moment conditions is set up following Hansen (1982). The results are reported in Table 7. This alternative estimation technique yields results that are practically identical to those reported in Table 5 , which suggests that measurement errors in FX exposure are not driving our results.

\section{TABLE 7}

\subsection{Time variation}

Bennett, et al. (2003) demonstrate that determinants of institutional holdings tend to change over time. It is therefore preferable to control for time variation in institutional ownership. Bennett, et al. (2003) also point out that the high growth rate of overall institutional holdings would further distort OLS-results, as scales of both dependent and independent variables vary greatly both across time, and across institution types. To take these potential problems into account, we next follow them in standardizing the variables that we use in our regressions, as follows. For each firm and each control variable, we calculate the deviation from the cross-sectional mean for that variable in that time period. This difference is then scaled by the standard deviation of the variable. The regression set up is described by equation (2), using the notation of Bennett, et al. (2003). 


$$
\left(\frac{y_{i}-\bar{y}}{s_{y}}\right)=\frac{b_{1} s_{1}}{s_{y}}\left(\frac{x_{i 1}-\bar{x}_{1}}{s_{1}}\right)+\cdots+\frac{b_{j} s_{j}}{s_{y}}\left(\frac{x_{i j}-\bar{x}_{j}}{s_{j}}\right)
$$

The results are reported in Table 8. As we follow Bennett, et al. (2003) in standardizing our variables, the interpretation of our regression coefficients differs slightly from the usual. Our coefficients in Table 8 represent the expected standard deviation change in each dependent variable, given a one standard deviation change in the independent variable.

\section{TABLE 8}

Our main results persist also in this specification. Banks tend to avoid FX exposure and investment firms and independent investment advisors are drawn to it. By and large, the control variables behave in a consistent manner in this specification when compared to the results reported earlier.

An alternative method to consider time variation in institutional preferences is to divide the sample into time-specific sub-samples. This setting allows us also to more specifically observe whether the shift from the prudent man rule to the prudent investor-type regulation has affected risk taking in institutional portfolios. The results of pooled OLS regressions with decade-by-decade subsamples are reported in Table 9.

\section{TABLE 9}

The first sub-sample in Panel A of Table 9 includes observations from 1983 to 1989. Bank trusts exhibit a lower preference for FX risk during the 1980s. The FX risk coefficients for investment firms and independent investment advisors are positive and significant. Insurance firms 
also exhibit an appetite for FX exposure. In Panel B of Table 9, we report findings for the 1990s subsample. Also in that time period, a clear pattern of less FX risk for banks and pension funds, and more FX risk for investment firms is present. In the most recent sub-period (Panel C of Table 9), the inverse relationship between bank holdings and FX risk practically disappears, with the regression coefficient becoming indistinguishable from zero. This finding is consistent with the reduced regulatory emphasis on asset-specific risk characteristics. It provides support for Del Guercio (1996) suggestion that the prudent man rule constrains bank risk taking, as the risk avoidance pattern has changed with the shift away from the prudent man rule. Our findings are also consistent with Hankins, et al. (2008) finding that institutional demand for dividend-paying stocks has shifted since the prudent man regulation has been replaced with regulation emphasizing risk at the portfolio level. It is interesting to note that the sign on the stock price variable has also shifted in the most recent time period, with investment and independent investment advisor categories exhibiting a preference for lower-priced stocks. The explanatory power of the model is higher in the most recent time period for most institution categories, with banks and investment firms showing most sizable increases in adjusted $\mathrm{R}^{2}$.

\subsection{Endogeneity and causality}

Many of the control variables we employ in our regressions, including even institutional ownership itself, are commonly used as explanatory variables in studies of FX risk management. Indeed, size and book-to-market (e.g. Graham and Rogers, 2002), and dividends (e.g. Allayannis and Weston, 2001) are found to be significant determinants of firms' hedging in previous studies. This leads to an obvious concern for endogeneity with our results. Furthermore, previous findings on the value of institutional owners as monitors, affecting firm behavior on issues such as R\&D spending (Bushee, 1998) and executive compensation (Hartzell and Starks, 2003), highlight the question about the direction of causality in our observed connection between FX exposure and 
institutional ownership. Also, Brav, et al. (2008) find that hedge funds can affect firm behavior through concentrated holdings in a small number of firms, both by themselves, and as a group, working together. In a recent study, Faccio, et al. (2010) find that among European firms, owners' portfolio diversification affects the firms' risk-taking, so that firms with more diversified owners tend to take more risk. However, their work is based on a dataset that includes both public and private European firms, and the average voting power of the largest shareholder in the dataset is $63.96 \%$. In that setting, it is more likely for causality to flow from ownership to risk-taking, whereas in our dataset, the average combined holdings of institutions is below $50 \%{ }^{13}$

We take the concern with endogeneity into account by defining a system of equations, where hedging decisions and institutional ownership are determined simultaneously. In our hedging model, we use variables that are commonly used in studies of determinants of hedging, namely (aggregate) institutional ownership, firm size $(\log ($ mcap$))$, book-to-market, proportion of foreign sales, R\&D expenses (R\&D/sales), Capital expenditures (Capex/sales), ROA, and leverage. We continue to use the same specification for institutional ownership that we have used in the previous tables. The dependent variable is FX exposure, measured by the absolute value of the $\beta_{\mathrm{FX}^{-}}$ coefficient in equation (1). In place of year dummies, we use a time trend variable, which reduces the number of regressors and thus improves identification of the system. We estimate the system with 3SLS, and the results are reported in Table 10.

\section{TABLE 10}

\footnotetext{
${ }^{13}$ Recall also that Sias (1996) explores the connection between volatility and institutional ownership and finds that increases in institutional ownership cause an increase in volatility, instead of institutional investors being drawn to firms with higher volatility. While institutional ownership is unlikely to cause changes in FX exposure directly, the presence (or potential presence) of institutions as shareholders could affect firm behavior.
} 
The results regarding institutional ownership by institution types are very similar to those reported earlier. Banks, and now also pension funds, exhibit a dislike for FX exposure, and investment firms and independent investment advisors exhibit a preference for it. Our hedging model yields inferences that are mostly consistent with existing studies. Like Graham and Rogers (2002), we find that size and book-to-market are negatively (positively) related to FX exposure (hedging activity), whereas firms with higher R\&D expenses exhibit higher FX exposure according to our model. ${ }^{14}$

We consider causality of the connection between institutional ownership and FX exposure by dividing institutional ownership into investment styles, instead of institution types. We use the dataset from Brian Bushee, who extracts institutional investors' investment styles from their trading behavior and portfolio characteristics, using a factor and cluster analysis approach (see Bushee, 1998). Each institution in the Thomson Financial database is classified as following a dedicated, transient, or quasi-indexer investment strategy. Dedicated investors are long-term investors who tend to make large investments in a limited number of stocks. Their dedicated nature gives them an incentive to actively monitor managers in the firms that they hold in their portfolios. Transient investors trade frequently and hold well-diversified portfolios. Quasi-indexers are also welldiversified, but they tend to follow a buy and hold strategy, and have a low portfolio turnover (Bushee, 1998). If the presence and the extent of institutional ownership affects corporate risk management behavior, for example through investor activism, then we expect this effect to be the strongest for firms with high levels of dedicated institutional ownership. Quasi-indexers should have a similar but perhaps weaker effect, as their incentives to affect management's decisions are lower due to their small stakes in individual firms. Transient institutions are the least likely group to

\footnotetext{
${ }^{14}$ Our full sample includes financial firms. As our hedging model contains variables that may behave differently between financial and industrial firms, we rerun our 3SLS model without the financial firms. Our 3SLS (and all other) results are unaffected by the exclusion of financials.
} 
exert power on management, as they are frequent traders and price takers by their nature. In Table 11, we report results based on the three investment style groups. In order to allow comparisons across investment styles, we use the standardized regression method described in equation (2), and used in Table 8.

\section{TABLE 11}

The results in Panel A of Table 11 reveal that while dedicated institutions do have a significant positive relation to FX exposure, the magnitude of the FX exposure coefficient is much smaller than that for the transient group, which group, again, is assumed to be tilted towards price taking instead of investor activism. Quasi-indexers exhibit a dislike for FX exposure, which is possibly explained by a large number of bank trusts and pension funds within that group. However, while the transient group is more likely to vote with their feet than to exert power on management, it is possible that firms cater to needs of those investors in order to attract them. ${ }^{15}$

For further evidence on causality, in Panel B of Table 11, we rerun the regressions in Panel A, using first differences of both institutional investment and our dependent variables. As Panel B of Table 11 reveals, changes in FX exposure do not affect the level of investment by transient or dedicated investors, who would be the most likely groups to react to catering. The only group with a significant reaction to changes in FX exposure is quasi-indexers, who reduce their holdings upon increases in FX exposure. The fact that changes in exposure are unrelated to changes in investments of transient and dedicated groups weakens the catering argument, as firms' FX exposure changes

\footnotetext{
${ }^{15}$ The catering argument is not in conflict with our main hypothesis, as it builds on institutions being attracted to firms with high FX risk.
} 
fail to affect holdings of the two types of institutions that are more likely to trade upon new information. $^{16}$

Yet another approach to examine causality is to observe the connection between concentration of institutional ownership and FX-risk, in line with the study by Grinstein and Michaely (2005) on dividends and institutional ownership. In case the presence of institutional ownership affects the firm's FX-risk management, we should expect that effect to be stronger when institutional ownership is more concentrated. In order to measure ownership concentration among institutional investors, we calculate the Herfindahl index of ownership proportions both for aggregate institutional holdings, and separately for each institution type. When we compare these Herfindahl indices between high and low FX-exposure quintiles in a setting similar to Panel B of Table 4, we find that institutional ownership concentration does not differ in a statistically significant way between firms with high and low absolute values of FX-exposure (results not reported). Our 3sls results presented earlier in Table 10 are also robust to inclusion of the institutional ownership concentration measure in the hedging model.

Lack of evidence on the connection between institutional ownership concentration and FX risk lends support for the notion that FX exposure attracts institutional investment, but that institutional investors with their power as shareholders do not affect FX risk management of firms. This is consistent with Grinstein and Michaely (2005), who find that institutional holdings depend on dividends, but that those holdings do not induce firms to alter their payout levels. Also, Parrino, et al. (2003) find that institutions tend to adjust their holdings down upon poor firm performance, rather than engaging in investor activism.

\footnotetext{
${ }^{16}$ We do not consider changes in FX exposure elsewhere in this study. The main reason is that since we estimate FX exposure over a three-year period, effects of any sudden changes are diminished and difficult to observe precisely. Against that background, it is surprising that changes in FX exposure enter with a significant sign for the quasi-indexer group in Panel B of Table 11.
} 
Finally, Brav, et al. (2008) explore hedge fund activism by studying the $13 \mathrm{~d}$ filings filed in connection with block investments. The filings contain information about the stated purpose of those investments that result in block holdings in excess of 5\%. We follow their approach and manually collect 13d filings from the SEC's Edgar database for those 4089 firms in our sample that exhibit significant shifts in the FX-exposure during our sample period. Our goal is to seek if institutional investors tend to actively pursue changes to firms' risk management practices. ${ }^{17} \mathrm{We}$ use search words "foreign exchange" and "risk management" in our search through $13 \mathrm{~d}$ filings. Either search word appears in 13d filings connected to 138 of the 4089 firms. While in most cases, the terms appear in clauses related to either hedging of a stock position subject to the agreement, or retention of the firm's normal risk management practices throughout a merger, we identify 16 cases in which either the block purchaser's risk management expertise is mentioned, or the purchaser is promoting a board member with risk management expertise. Coincidentally, large shifts in FXexposure tend to occur subsequent to such filings, especially in the latter case. However, our results are robust to excluding the indicated firms from our analysis.

\section{Conclusions}

We study the relation between FX exposure and institutional ownership between 1980 and 2007 in the U.S. We argue, along with DeMarzo and Duffie (1991), that better-informed investors should be more capable of home-made hedging. This leads to a prediction of a positive relation between the level of institutional ownership and FX exposure. Institutions' ability to manage risks both on their balance sheets and with derivatives should further increase their ability to carry FX

\footnotetext{
${ }^{17}$ Unlike Brav, et al. (2008), who focus on hedge fund activism and therefore only study $13 \mathrm{~d}$ filings made by hedge funds, we analyze all 13d filings and amendments subject to firms whose FX-exposure experiences a shift during our sample period. We specify a significant shift as a move of a minimum of two FX-exposure quintiles over a maximum of a three year period.
} 
exposure. We further find evidence of FX risk being a priced factor, which gives institutions the motivation to use their ability to carry FX risk.

We also consider FX risk management within institutional portfolios by observing negative and positive FX exposures of each institution separately. We find that institutions with high negative exposure stocks tend to also carry stocks with high positive exposure in their portfolios. Overall, our results suggest that institutions consider FX exposure in their portfolio construction, and that they actively manage it. FX risk also appears to be a relevant risk for the legal viewpoint, as we find that institutional behavior with respect to the prudent man regulation follows patterns that are similar to those reported in earlier studies regarding variables such as dividends and stock volatility.

Our study contributes to the growing literature on determinants of institutional holdings. A recent study by Davies, et al. (2010) is perhaps closest to our paper. They explore pure industry risks and their effect on institutional holdings. Similar to our findings, they report that institutions are drawn to diversifiable risks, while prudence standards reduce this preference. 


\section{REFERENCES}

Adler, M., and B. Dumas, 1984, "Exposure to currency risk: Definition and measurement", Financial Management 13, 41-50.

Allayannis, G., and J. Weston, 2001, "The use of foreign currency derivatives and firm market value", Review of Financial Studies 14, 243-276.

Ang, A., R.J. Hodrick, Y. Xing, and X. Zhang, 2009, "High idiosyncratic volatility and low returns: International evidence and further U.S. evidence", Journal of Financial Economics 91, 1-23.

Badrinath, S.G., J.R. Kale, and H.E. Ryan, 1996, "Characteristics of Common Stock Holdings of Insurance Companies", Journal of Risk and Insurance 63, 49-76.

Barber, B.M., and T. Odean, 2008, "All That Glitters: The Effect of Attention and News on the Buying Behavior of Individual and Institutional Investors", Review of Financial Studies 21, 785818.

Bartov, E., and G.M. Bodnar, 1994, "Firm valuation, earnings expectations, and the exchange rate exposure effect", Journal of Finance 49, 1755-1785.

Bartram, S., G.W. Brown, and B.A. Minton, 2010, "Resolving the exposure puzzle: The many facets of exchange rate exposure", Journal of Financial Economics 95, 148-173.

Bennett, J.A., R.W. Sias, and L.T. Starks, 2003, "Greener Pastures and the Impact of Dynamic Institutional Preferences”, Review of Financial Studies 16, 1203-1238.

Brav, A., and J.B. Heaton, 1998, "Did ERISA's prudent man rule change the pricing of dividend omitting firms?", Duke University working paper.

Brav, A., W. Jiang, F. Partnoy, and R. Thomas, 2008, "Hedge fund activism, corporate governance, and firm performance, Journal of Finance 63, 1729-1775.

Bushee, B.J., 1998, "The Influence of Institutional Investors on Myopic R\&D Investment Behavior”, Accounting Review 73, 305-333.

Bushee, B.J., 2001, “Do Institutional Investors Prefer Near-Term Earnings over Long-Run Value?”, Contemporary Accounting Research 18, 207-246.

Bushee, B.J., and C.F. Noe, 2000, "Corporate Disclosure Practices, Institutional Investors, and Stock Return Volatility", Journal of Accounting Research 38, 171-202.

Carhart, M.M., 1997, “On Persistence in Mutual Fund Performance”, Journal of Finance 52, 57-82.

Carrieri, F., V. Errunza, and B. Majerbi, 2006, "Does emerging market exchange risk affect global equity prices?”, Journal of Financial and Quantitative Analysis 41, 511-540.

Chen, Y-C., K. Rogoff, and B. Rossi, 2010, "Can exchange rates forecast commodity prices?", Quarterly Journal of Economics, forthcoming. 
Choi, J.J., and A.M. Prasad, 1995, "Exchange risk sensitivity and its determinants: a firm and industry analysis of U.S. multinationals", Financial Management 24, 77-88.

Choi, N., and R.W. Sias, 2009, "Institutional industry herding", Journal of Financial Economics 94, 469-491.

Chung, K.H., and H. Zhang, 2009, “Corporate Governance and Institutional Ownership", Journal of Financial and Quantitative Analysis, forthcoming.

Davies, P., B.A. Minton, and C. Schrand, 2010, "Investor clienteles and industry factor-price exposure", unpublished working paper.

Del Guercio, D., 1996, “The Distorting Effect of the Prudent-Man Laws on Institutional Equity Investment", Journal of Financial Economics 40, 31-62.

DeMarzo, P.M., and D. Duffie, 1991, "Corporate Financial Hedging with Proprietary Information", Journal of Economic Theory 53, 261-286.

DeSantis, G., and B. Gerard, 1998, "How big is the premium for currency risk?", Journal of Financial Economics 49, 375-412.

Dominguez, K.M.E., and L.L. Tesar, 2001, "A re-examination of exchange rate exposure", American Economic Review 91, 396-399.

Faccio, M., M.-T. Marchica, and R. Mura, 2010, "Large shareholder diversification and corporate risk-taking", unpublished working paper.

Fama, E.F., and K.R. French, 1992, "The cross-section of expected stock returns", Journal of Finance 47, 427-465.

Federal Reserve, 2010, H10 Foreign exchange rates. At

http://federalreserve.gov/releases/H10/Weights/.

Ferreira, M.A., and P. Matos, 2008, "The colors of investors' money: The role of institutional investors around the world", Journal of Financial Economics 88, 499-533.

Francis, B.B., I. Hasan, and D.M. Hunter, 2008, "Can hedging tell the full story? Reconciling differences in United States aggregate- and industry-level exchange risk premium", Journal of Financial Economics 90, 169-196.

Gompers, P.A., A. Metrick, 2001, "Institutional Investors and Equity Prices", Quarterly Journal of Economics 116, 229-259.

Graham, J.R., and D.A. Rogers, 2002, "Do firms hedge in response to tax incentives", Journal of Finance 62, 815-839.

Grinstein, Y., and R. Michaely, 2005, "Institutional holdings and payout policy", Journal of Finance 60, 1389-1426. 
Grullon, G., G. Kanatas, and J.P. Weston, 2004, "Advertising, Breath of Ownership, and Liquidity", Review of Financial Studies 17, 439-461.

Guay, W., and S.P. Kothari, 2003, "How much do firms hedge with derivatives?", Journal of Financial Economics 70, 423-461.

Hankins, K.W., M.J. Flannery, and M. Nimalendran, 2008, "The effect of fiduciary standards on institutions' preference for dividend-paying stocks", Financial Management 37, 647-671.

Hansen, L.P., 1982, "Large sample properties of generalized method of moments estimators", Econometrica 50, 1029-1054.

Hartzell, J.C., and L.T. Starks, 2003, "Institutional Investors and Executive Compensation", Journal of Finance 58, 2351-2374.

Hong, H., M. Kacperczyk, 2009, "The price of sin: The effects of social norms on markets", Journal of Financial Economics 93, 15-36.

Jin, Y., and P. Jorion, 2006, "Firm Value and Hedging: Evidence from U.S. Oil and Gas Producers", Journal of Finance 61, 893-919.

Jorion, P., 1990, "The exchange-rate exposure of U.S. multinationals", Journal of Business 63, 331345 .

Modigliani, F., and M. Miller, 1958, "The Cost of Capital, Corporation Finance, and the Theory of Investment”, American Economic Review 48, 261-297.

Newey, W.K., and K.D. West, 1987, “A Simple, Positive Semi-Definite, Heteroskedasticity and Autocorrelation Consistent Covariance Matrix", Econometrica 55, 703-708.

Parrino, R., R.W. Sias, and L.T. Starks, 2003, "Voting with their feet: institutional ownership changes around forced CEO turnover", Journal of Financial Economics 68, 3-46.

Pastor, L., and R.F. Stambaugh, 2003, "Liquidity risk and expected stock returns", Journal of Political Economy 111, 642-685.

Petersen, M.A., and S.R. Thiagarajan, 2000, "Risk Measurement and Hedging: With and without Derivatives", Financial Management 29, 5-29.

Schanzenbach, M.M., and R.H. Sitkoff, 2007, "Did reform of prudent trust investment laws change trust portfolio allocation?", Journal of Law and Economics 50, 681-711.

Shanken, J., 1992, "On the Estimation of Beta-Pricing Models", Review of Financial Studies 5, 133.

Sias, R.W., 1996, "Volatility and the Institutional Investor”, Financial Analyst Journal 52:2, 13-20.

Smith, C.W., Jr., and R.M. Stulz, 1985, "The determinants of firms' hedging policies", Journal of Financial and Quantitative Analysis 20, 391-405. 


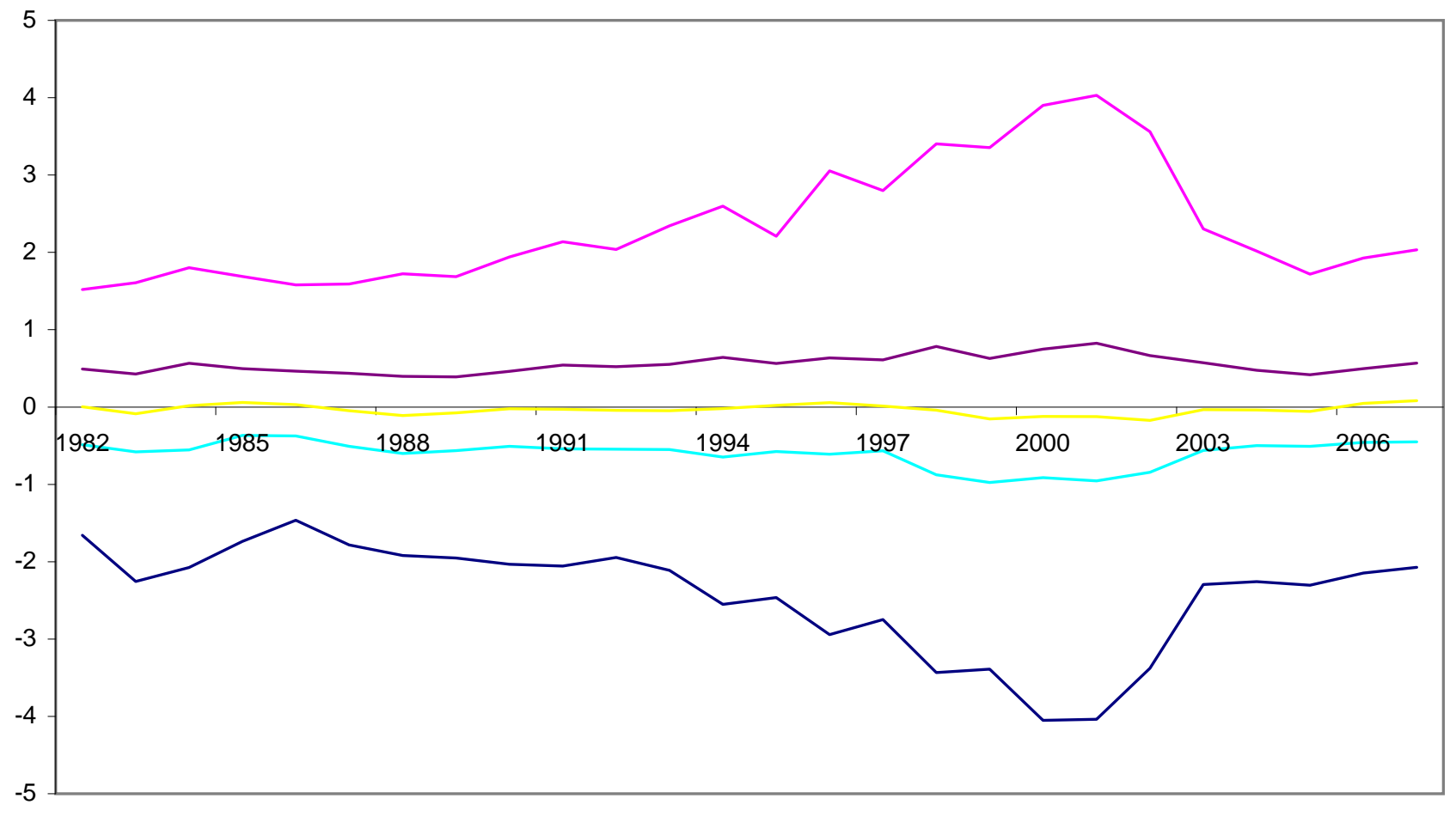

Figure 1. Average FX exposure coefficient by quantile 


\section{Table 1: Institutional Ownership by Year and Institution Type}

\begin{tabular}{|c|c|c|c|c|c|c|c|c|}
\hline year & $\mathrm{N}$ & Aggregate & Bank & Insurance & Investment & $\| A$ & Pension & Misc. \\
\hline 1980 & 3017 & 0.1706 & 0.0697 & 0.0201 & 0.0143 & 0.0510 & 0.0143 & 0.0013 \\
\hline 1981 & 3200 & 0.1707 & 0.0699 & 0.0198 & 0.0143 & 0.0509 & 0.0147 & 0.0012 \\
\hline 1982 & 3258 & 0.1803 & 0.0692 & 0.0210 & 0.0155 & 0.0593 & 0.0142 & 0.0011 \\
\hline 1983 & 3824 & 0.1868 & 0.0626 & 0.0201 & 0.0157 & 0.0736 & 0.0140 & 0.0008 \\
\hline 1984 & 3961 & 0.2012 & 0.0635 & 0.0192 & 0.0183 & 0.0866 & 0.0129 & 0.0007 \\
\hline 1985 & 3937 & 0.2241 & 0.0659 & 0.0196 & 0.0176 & 0.1052 & 0.0152 & 0.0007 \\
\hline 1986 & 4095 & 0.2398 & 0.0685 & 0.0193 & 0.0162 & 0.1202 & 0.0148 & 0.0007 \\
\hline 1987 & 4404 & 0.2401 & 0.0647 & 0.0197 & 0.0179 & 0.1225 & 0.0148 & 0.0006 \\
\hline 1988 & 4227 & 0.2462 & 0.0663 & 0.0213 & 0.0170 & 0.1236 & 0.0173 & 0.0006 \\
\hline 1989 & 4190 & 0.2534 & 0.0688 & 0.0215 & 0.0154 & 0.1280 & 0.0191 & 0.0007 \\
\hline 1990 & 3937 & 0.2751 & 0.0625 & 0.0219 & 0.0187 & 0.1500 & 0.0212 & 0.0008 \\
\hline 1991 & 3996 & 0.2776 & 0.0570 & 0.0207 & 0.0317 & 0.1474 & 0.0198 & 0.0010 \\
\hline 1992 & 4608 & 0.2817 & 0.0541 & 0.0196 & 0.0349 & 0.1529 & 0.0190 & 0.0010 \\
\hline 1993 & 5357 & 0.2742 & 0.0492 & 0.0195 & 0.0395 & 0.1488 & 0.0165 & 0.0009 \\
\hline 1994 & 6022 & 0.2857 & 0.0496 & 0.0233 & 0.0398 & 0.1551 & 0.0172 & 0.0008 \\
\hline 1995 & 6303 & 0.2991 & 0.0468 & 0.0235 & 0.0451 & 0.1645 & 0.0184 & 0.0008 \\
\hline 1996 & 6668 & 0.2983 & 0.0519 & 0.0236 & 0.0464 & 0.1627 & 0.0131 & 0.0007 \\
\hline 1997 & 6998 & 0.3168 & 0.0563 & 0.0230 & 0.0524 & 0.1704 & 0.0140 & 0.0006 \\
\hline 1998 & 6828 & 0.3205 & 0.0557 & 0.0252 & 0.0547 & 0.1686 & 0.0149 & 0.0015 \\
\hline 1999 & 6505 & 0.3260 & 0.0533 & 0.0252 & 0.0515 & 0.1813 & 0.0132 & 0.0014 \\
\hline 2000 & 6491 & 0.3212 & 0.0504 & 0.0216 & 0.0538 & 0.1752 & 0.0170 & 0.0032 \\
\hline 2001 & 5465 & 0.3663 & 0.0573 & 0.0241 & 0.0605 & 0.2015 & 0.0182 & 0.0048 \\
\hline 2002 & 4930 & 0.3998 & 0.0669 & 0.0247 & 0.0648 & 0.2165 & 0.0193 & 0.0076 \\
\hline 2003 & 5007 & 0.4029 & 0.0687 & 0.0231 & 0.0631 & 0.2156 & 0.0179 & 0.0146 \\
\hline 2004 & 5186 & 0.4318 & 0.0765 & 0.0233 & 0.0658 & 0.2309 & 0.0178 & 0.0174 \\
\hline 2005 & 5160 & 0.4459 & 0.0780 & 0.0223 & 0.0656 & 0.2412 & 0.0179 & 0.0208 \\
\hline 2006 & 5124 & 0.4679 & 0.0801 & 0.0209 & 0.0668 & 0.2614 & 0.0167 & 0.0220 \\
\hline 2007 & 4935 & 0.4746 & 0.0796 & 0.0210 & 0.0638 & 0.2712 & 0.0161 & 0.0229 \\
\hline
\end{tabular}




\section{Table 2: Pricing of FX Exposure}

The table reports monthly alphas and raw returns for quintiles based on the FX exposure in percentages. The sorting is based on different versions of the CAPM, as indicated in each panel header. Alphas based on the CAPM, the FamaFrench 3-factor model, and the Carhart 4-factor model are reported in respective columns. The right-most column reports the raw returns for each quintile. The last two rows of each panel report the difference between the high and the low quintile, and the t-statistic of the difference, with the asterisks indicating statistical significance at one percent (***), five percent $\left({ }^{\star *}\right)$, and ten percent $\left({ }^{*}\right)$ levels, respectively..

Panel A: Sorting based on the absolute value of the CAPM FX risk coefficient

\begin{tabular}{lcccc}
\hline & CAPM & 3lphas & \\
\hline Q1-High & 1.2954 & 1.4671 & 1.5625 & Raw returns \\
Q2 & 0.8925 & 0.9747 & 0.9729 & 2.6316 \\
Q3 & 0.6306 & 0.6043 & 0.5847 & 2.0536 \\
Q4 & 0.6247 & 0.5537 & 0.5788 & 1.6717 \\
Q5-Low & 0.5759 & 0.5281 & 0.5041 & 1.6947 \\
High-Low & 0.7196 & 0.9389 & 1.0584 & 1.5611 \\
tstat & $2.399^{\star \star}$ & $4.008^{\star \star \star}$ & $4.230^{\star \star \star}$ & 1.0705 \\
\hline
\end{tabular}

Panel B: Sorting based on the absolute value of the 3-factor FX risk coefficient

\begin{tabular}{lcccc}
\hline & CAPM & 3lphas & \\
\hline Q1-High & 1.1918 & 1.2702 & 1.3248 & Raw returns \\
Q2 & 0.8652 & 1.0350 & 1.0252 & 2.5345 \\
Q3 & 0.6105 & 0.5535 & 0.5833 & 2.0399 \\
Q4 & 0.6422 & 0.5938 & 0.5832 & 1.6778 \\
Q5-Low & 0.6238 & 0.5451 & 0.5198 & 1.6993 \\
High-Low & 0.5680 & 0.7251 & 0.8049 & 1.6037 \\
tstat & $2.053^{\star \star}$ & $4.020^{\star \star \star}$ & $4.588^{\star \star \star}$ & 0.9308 \\
\hline
\end{tabular}

Panel C: Sorting based on the absolute value of the 4-factor FX risk coefficient

\begin{tabular}{lcccc}
\hline & CAPM & 3lphas & & \\
& 3-factor & 4-factor & Raw returns \\
\hline Q1-High & 1.2123 & 1.3082 & 1.3551 & 2.5366 \\
Q2 & 0.8576 & 1.0876 & 1.0877 & 2.0380 \\
Q3 & 0.6166 & 0.5556 & 0.5703 & 1.6842 \\
Q4 & 0.6619 & 0.6163 & 0.5808 & 1.7132 \\
Q5-Low & 0.6056 & 0.4960 & 0.4955 & 1.5878 \\
High-Low & 0.6068 & 0.8123 & 0.8596 & 0.9488 \\
tstat & $2.203^{\star \star}$ & $4.606^{\star \star \star}$ & $5.531^{\star \star \star}$ & $3.306^{\star \star \star}$ \\
\hline
\end{tabular}




\section{Table 3: Diversification of FX exposure}

The table reports average FX exposures of institutional portfolios by quintiles, where quintiles are sorted based on the negative exposures. The exposures are calculated using the CAPM, the Fama-French 3-factor model, and the Carhart 4-factor model in respective columns.

\begin{tabular}{lcc|cc|cc} 
& \multicolumn{2}{c}{ CAPM } & \multicolumn{2}{c}{ 3-Factor Model } & \multicolumn{2}{c}{ 4-Factor Model } \\
& pos exp. & neg.exp. & pos exp. & neg.exp. & pos exp. & neg.exp. \\
\hline Q1-High & 1.0931 & -1.2629 & 1.1092 & -1.3055 & 1.1403 & -1.3312 \\
Q2 & 0.8581 & -0.8626 & 0.8560 & -0.8874 & 0.8765 & -0.8968 \\
Q3 & 0.7513 & -0.7245 & 0.7396 & -0.7416 & 0.7555 & -0.7470 \\
Q4 & 0.6785 & -0.6253 & 0.6612 & -0.6355 & 0.6739 & -0.6398 \\
Q5-Low & 0.6397 & -0.5014 & 0.6103 & -0.5062 & 0.6208 & -0.5100 \\
\hline
\end{tabular}




\section{Table 4: Institutional Ownership by FX Exposure Quintiles and Institution Types}

The table reports average institutional holdings in quintiles based on FX exposure. The FX exposure is estimated using equation (1). Institution types are based on data in Thomson Financial database, corrected by Brian Bushee. The last column indicates the average FX exposure in each quintile. The quintiles in Panel A are based on the values of the FX-exposure coefficient in equation (1), while Panel B is based on the absolute values of FX-exposure. The bottom row of Panel B indicates the t-statistics for a difference in holdings between the highest and the lowest quintiles in the Panel, with the asterisks indicating statistical significance at one percent $\left(^{\star \star *}\right)$, five percent $\left(^{\star *}\right)$, and ten percent $\left({ }^{*}\right)$ levels, respectively.

\begin{tabular}{lcccccccc}
\multicolumn{1}{c}{ Panel A: Quantiles sorted based on the FX risk coefficient } \\
\hline & Aggregate & Bank & Insurance & Investment & IIA & Pension & Misc. & Avg. FX exp \\
Q1-High & 0.3146 & 0.0578 & 0.0213 & 0.0425 & 0.1727 & 0.0161 & 0.0043 & 2.3289 \\
Q2 & 0.3318 & 0.0730 & 0.0249 & 0.0431 & 0.1672 & 0.0194 & 0.0042 & 0.5530 \\
Q3 & 0.2951 & 0.0686 & 0.0233 & 0.0369 & 0.1452 & 0.0173 & 0.0038 & -0.0344 \\
Q4 & 0.3039 & 0.0667 & 0.0234 & 0.0394 & 0.1526 & 0.0173 & 0.0045 & -0.6009 \\
Q5-Low & 0.2923 & 0.0524 & 0.0198 & 0.0398 & 0.1616 & 0.0143 & 0.0045 & -2.4255
\end{tabular}

Panel B: Quantiles sorted based on the absolute value of the FX risk coefficient

\begin{tabular}{lcccccccc}
\hline & Aggregate & Bank & Insurance & Investment & IIA & Pension & Misc. & Avg. FX exp \\
Q1-High & 0.2786 & 0.0468 & 0.0179 & 0.0378 & 0.1586 & 0.0133 & 0.0041 & 3.4286 \\
Q2 & 0.3284 & 0.0633 & 0.0231 & 0.0444 & 0.1758 & 0.0170 & 0.0047 & 1.3285 \\
Q3 & 0.3240 & 0.0695 & 0.0244 & 0.0426 & 0.1646 & 0.0185 & 0.0045 & 0.7553 \\
Q4 & 0.3087 & 0.0699 & 0.0238 & 0.0395 & 0.1534 & 0.0180 & 0.0042 & 0.4034 \\
Q5-Low & 0.2981 & 0.0690 & 0.0235 & 0.0374 & 0.1469 & 0.0175 & 0.0038 & 0.1279 \\
High-Low & -0.0195 & -0.0222 & -0.0056 & 0.0004 & 0.0117 & -0.0041 & 0.0003 & 0.671 \\
tstat & $-2.018^{\star \star}$ & $-10.638^{\star \star \star}$ & $-10.661^{\star \star \star}$ & 0.417 & $2.069^{\star \star}$ & $-6.096^{\star \star \star}$ & 0 \\
\hline
\end{tabular}


Table 5: Institutional Ownership and FX Exposure - Pooled OLS Regressions by Institutional Classification

The table reports OLS results, with the proportion of institutional holdings by each institution type indicated in respective columns. The FX exposure is estimated using equation (1). SIZE is the natural logarithm of the market capitalization of equity, $\log (\mathrm{b} / \mathrm{m})$ is the natural logarithm of the ratio of the book value of equity to the market capitalization of equity, $\mathrm{RET}_{-12,0}$ is the stock return in the 12 months preceeding the observation year-end, 1/Price is the inverse of the firm's stock price at the end of the year, DIVYIELD is the annual dividend over the year-end stock price, and S\&P 500 is an indicator variable that takes on the value of one for the members of the S\&P 500 index, zero otherwise. Institution types are based on data in

Thomson Financial database, corrected by Brian Bushee. T-statistics robust for heteroskedasticity and autocorrelation are repoted in the parentheses, with the asterisks indicating statistical significance at one percent $\left.{ }^{* * *}\right)$, five percent $\left(^{* *}\right)$, and ten percent $\left(^{*}\right)$ levels, respectively.

\begin{tabular}{|c|c|c|c|c|c|c|c|}
\hline & Aggregate & Bank & Insurance & Investment & IIA & Pension & Misc. \\
\hline \multirow[t]{2}{*}{ Fx Exposure } & $0.0068^{\star \star \star}$ & $-0.0014^{\star \star \star}$ & 0.0002 & $0.0021^{\star \star \star}$ & $0.0059 * *$ & 0.0001 & 0.0000 \\
\hline & (8.924) & $(-5.404)$ & (0.919) & (11.030) & $(12.304)$ & (1.417) & $(-0.389)$ \\
\hline \multirow[t]{2}{*}{ SIZE } & $0.0840^{* * *}$ & $0.0169 * \star \star$ & $0.0105^{\star * *}$ & $0.0137^{* \star \star}$ & $0.0352^{\star \star \star}$ & $0.0065^{\star \star \star}$ & $0.0011^{* * *}$ \\
\hline & (112.722) & (68.146) & $(61.454)$ & (75.245) & (75.749) & (64.325) & (11.853) \\
\hline \multirow[t]{2}{*}{$\log (b / m)$} & $0.0224^{\star \star \star}$ & $0.0055^{\star \star \star}$ & $0.0034^{\star * *}$ & -0.0005 & $0.0100 * * \star$ & $0.0026^{\star \star \star}$ & $0.0014^{\star * *}$ \\
\hline & (15.578) & (11.564) & $(10.247)$ & $(-1.415)$ & (11.185) & (13.235) & (7.360) \\
\hline \multirow[t]{2}{*}{ RET $_{-12,0}$} & $-0.0004^{* * *}$ & $-0.0001^{\star \star *}$ & $-0.0001^{* * *}$ & $-0.0001^{* \star *}$ & $-0.0001^{* * *}$ & $-0.0001^{\star \star \star}$ & $0.0000^{\star *}$ \\
\hline & $(-14.380)$ & $(-14.609)$ & $(-8.247)$ & $(-8.138)$ & $(-6.034)$ & $(-15.740)$ & (2.087) \\
\hline \multirow[t]{2}{*}{ 1/Price } & $-0.1583^{\star \star *}$ & $-0.2063^{\star * *}$ & $0.0119 *$ & $0.0276^{\star \star \star}$ & 0.0228 & 0.0005 & $-0.0147^{\star \star \star}$ \\
\hline & $(-5.800)$ & $(-22.692)$ & (1.888) & (4.127) & (1.338) & $(0.135)$ & $(-4.177)$ \\
\hline \multirow[t]{2}{*}{ DIVYIELD } & $-0.0217^{* * *}$ & $-0.0031^{\star * *}$ & $-0.0020^{* * *}$ & $-0.0024^{\star * *}$ & $-0.0124^{\star \star *}$ & $-0.0013^{\star \star \star}$ & $-0.0004^{\star \star \star}$ \\
\hline & $(-61.148)$ & $(-26.497)$ & $(-24.980)$ & $(-27.941)$ & $(-55.996)$ & $(-27.677)$ & $(-8.323)$ \\
\hline \multirow[t]{2}{*}{ S\&P 500} & $0.0761^{\star \star \star}$ & $0.0397^{\star \star \star}$ & $0.0021^{\star \star *}$ & $0.0081^{* \star \star}$ & $0.0096 * * \star$ & $0.0189 * \star \star$ & $-0.0023^{\star \star \star}$ \\
\hline & (31.146) & (48.815) & (3.697) & (13.623) & (6.314) & (57.049) & $(-7.435)$ \\
\hline \multirow{2}{*}{$\begin{array}{l}\text { Industry dummies } \\
\text { Year dummies }\end{array}$} & yes & yes & yes & yes & yes & yes & yes \\
\hline & yes & yes & yes & yes & yes & yes & yes \\
\hline Adj $R^{2}$ & 0.45 & 0.34 & 0.13 & 0.33 & 0.29 & 0.29 & 0.09 \\
\hline
\end{tabular}




\section{Table 6: Fama-MacBeth Regressions by Institutional Classification}

The table reports Fama-MacBeth regression results, with the proportion of institutional holdings by each institution type indicated in respective columns. The reported coefficients are averaged from annual regressions from 1983 to 2008 , and the dependent variables in each annual regression represent averages of those variables for each firm for the three years, during which the FX exposure is estimated. The variables are defined in Table III. T-statistics are repoted in the parentheses, with the asterisks indicating statistical significance at one percent $\left({ }^{* \star *}\right)$, five percent $\left({ }^{* \star}\right)$, and ten percent $\left({ }^{*}\right)$ levels, respectively.

\begin{tabular}{|c|c|c|c|c|c|c|c|}
\hline & Aggregate & Bank & Insurance & Investment & IIA & Pension & Misc. \\
\hline Fx Exposure & $\begin{array}{c}0.1334^{\star \star \star} \\
(2.727)\end{array}$ & $\begin{array}{c}-0.2097^{\star \star *} \\
(-2.645)\end{array}$ & $\begin{array}{c}0.1034^{\star \star} \\
(2.085)\end{array}$ & $\begin{array}{c}0.2786 * \star \star \\
(3.640)\end{array}$ & $\begin{array}{c}0.2083^{\star \star \star} \\
(3.512)\end{array}$ & $\begin{array}{l}0.0427 \\
(0.749)\end{array}$ & $\begin{array}{c}0.0898^{\star \star} \\
(2.365)\end{array}$ \\
\hline SIZE & $\begin{array}{c}3.6002^{\star \star \star} \\
(3.880)\end{array}$ & $\begin{array}{c}2.2418^{\star \star \star} \\
(3.761)\end{array}$ & $\begin{array}{c}1.9433^{\star \star \star} \\
(3.802)\end{array}$ & $\begin{array}{c}2.2206^{\star \star \star} \\
(3.515)\end{array}$ & $\begin{array}{c}2.3670 * \star \star \\
(3.854)\end{array}$ & $\begin{array}{c}2.1653^{\star \star \star} \\
(3.709)\end{array}$ & $\begin{array}{c}0.3404^{* * *} \\
(2.608)\end{array}$ \\
\hline $\log (b / m)$ & $\begin{array}{c}0.9189 * \star * \\
(3.768)\end{array}$ & $\begin{array}{c}0.4117^{\star \star \star} \\
(3.818)\end{array}$ & $\begin{array}{c}0.4315^{\star \star \star} \\
(3.381)\end{array}$ & $\begin{array}{c}0.3528 * \star \star \\
(3.289)\end{array}$ & $\begin{array}{c}0.7777^{\star \star *} \\
(3.432)\end{array}$ & $\begin{array}{c}0.4588^{\star * \star} \\
(3.767)\end{array}$ & $\begin{array}{c}0.3043^{* * *} \\
(3.486)\end{array}$ \\
\hline RET $_{-12,0}$ & $\begin{array}{c}-0.3823^{\star \star \star} \\
(-2.744)\end{array}$ & $\begin{array}{c}-0.4576^{\star \star \star} \\
(-3.467)\end{array}$ & $\begin{array}{c}-0.2061^{\star *} \\
(-2.042)\end{array}$ & $\begin{array}{r}-0.20 \\
(-1.75\end{array}$ & $\begin{array}{c}-0.0890 \\
(-0.896)\end{array}$ & $\begin{array}{c}-0.5247^{\star \star \star} \\
(-3.472)\end{array}$ & $\begin{array}{c}0.1304^{\star \star \star} \\
(2.926)\end{array}$ \\
\hline 1/Price & $\begin{array}{c}-0.8629 * * * \\
(-4.109)\end{array}$ & $\begin{array}{c}-0.8319 * * * \\
(-4.065)\end{array}$ & $\begin{array}{c}0.1259 * \star \star \\
(3.214)\end{array}$ & $\begin{array}{c}-0.3449 * * * \\
(-2.561)\end{array}$ & $\begin{array}{c}-0.5120 * \star * \\
(-3.247)\end{array}$ & $\begin{array}{c}0.0275 \\
(0.537)\end{array}$ & $\begin{array}{c}-0.1834^{\star *} \\
(-2.304)\end{array}$ \\
\hline DIVYIELD & $\begin{array}{c}-1.7160 * \star \star \\
(-3.770)\end{array}$ & $\begin{array}{c}-0.7732^{\star \star \star} \\
(-3.490)\end{array}$ & $\begin{array}{c}-0.7406^{\star * \star} \\
(-3.747)\end{array}$ & $\begin{array}{c}-1.1193^{\star \star \star} \\
(-3.711)\end{array}$ & $\begin{array}{c}-1.4616^{\star \star \star} \\
(-3.839)\end{array}$ & $\begin{array}{c}-0.6399 * \star \star \\
(-2.937)\end{array}$ & $\begin{array}{c}-0.1337^{*} \\
(-1.647)\end{array}$ \\
\hline S\&P 500 & $\begin{array}{c}0.9317^{\star \star *} \\
(3.607)\end{array}$ & $\begin{array}{c}1.4326^{\star \star \star} \\
(3.854)\end{array}$ & $\begin{array}{c}0.2122^{\star \star \star} \\
(2.887)\end{array}$ & $\begin{array}{c}0.5994^{\star * \star} \\
(3.348)\end{array}$ & $\begin{array}{l}0.0597 \\
(0.428)\end{array}$ & $\begin{array}{c}1.6166^{\star \star \star} \\
(3.144)\end{array}$ & $\begin{array}{c}-0.1577^{* *} \\
(-2.329)\end{array}$ \\
\hline Industry dummies & yes & yes & yes & yes & yes & yes & yes \\
\hline Adj $R^{2}$ & 0.47 & 0.36 & 0.14 & 0.24 & 0.27 & 0.32 & 0.01 \\
\hline
\end{tabular}




\section{Table 7: GMM Results by Institutional Classification}

The table reports GMM results, with the proportion of institutional holdings by each institution type indicated in respective columns. The variables are defined in Table III. T-statistics are repoted in the parentheses, with the asterisks indicating statistical significance at one percent $\left(^{* *}\right)$, five percent $\left({ }^{*}\right)$, and ten percent $\left({ }^{*}\right)$ levels, respectively.

\begin{tabular}{|c|c|c|c|c|c|c|c|}
\hline & Aggregate & Bank & Insurance & Investment & IIA & Pension & Misc. \\
\hline Fx Exposure & $\begin{array}{c}0.0068^{\star \star \star} \\
(6.650)\end{array}$ & $\begin{array}{c}-0.0014^{\star \star \star} \\
(-5.350)\end{array}$ & $\begin{array}{c}0.0002 \\
(0.750)\end{array}$ & $\begin{array}{c}0.0021^{\star \star \star} \\
(7.850)\end{array}$ & $\begin{array}{c}0.0059 * \star \star \\
(8.510)\end{array}$ & $\begin{array}{c}0.0001 \\
(1.280)\end{array}$ & $\begin{array}{l}0.0000 \\
(-0.560)\end{array}$ \\
\hline SIZE & $\begin{array}{c}0.0840 * \star \star \\
(64.960)\end{array}$ & $\begin{array}{c}0.0169 * * * \\
(42.910)\end{array}$ & $\begin{array}{c}0.0105^{\star \star \star} \\
(32.500)\end{array}$ & $\begin{array}{c}0.0137^{\star \star \star} \\
(44.410)\end{array}$ & $\begin{array}{c}0.0352^{\star \star \star} \\
(45.880)\end{array}$ & $\begin{array}{c}0.0065^{\star \star \star} \\
(44.480)\end{array}$ & $\begin{array}{c}0.0011^{* \star *} \\
(6.370)\end{array}$ \\
\hline $\log (b / m)$ & $\begin{array}{c}0.0224^{\star * *} \\
(9.670)\end{array}$ & $\begin{array}{c}0.0055^{\star \star \star} \\
(7.080)\end{array}$ & $\begin{array}{c}0.0034^{\star \star \star} \\
(5.800)\end{array}$ & $\begin{array}{c}-0.0005 \\
(-0.840)\end{array}$ & $\begin{array}{c}0.0100 * \star * \\
(7.020)\end{array}$ & $\begin{array}{c}0.0026 * * * \\
(9.170)\end{array}$ & $\begin{array}{c}0.0014^{\star \star \star} \\
(4.270)\end{array}$ \\
\hline RET $_{-12,0}$ & $\begin{array}{c}-0.0004^{* * *} \\
(-10.580)\end{array}$ & $\begin{array}{c}-0.0001^{\star * \star} \\
(-11.320)\end{array}$ & $\begin{array}{c}-0.0001^{\star \star \star} \\
(-6.840)\end{array}$ & $\begin{array}{c}-0.0001^{\star \star \star} \\
(-6.090)\end{array}$ & $\begin{array}{c}-0.0001^{\star \star *} \\
(-4.370)\end{array}$ & $\begin{array}{c}-0.0001^{\star * *} \\
(-11.870)\end{array}$ & $\begin{array}{c}0.0000 * \\
(1.800)\end{array}$ \\
\hline 1/Price & $\begin{array}{c}-0.1583^{\star \star *} \\
(-3.990)\end{array}$ & $\begin{array}{c}-0.2063^{\star \star \star} \\
(-16.090)\end{array}$ & $\begin{array}{l}0.0119 \\
(1.300)\end{array}$ & $\begin{array}{c}0.0276^{\star \star \star} \\
(2.890)\end{array}$ & $\begin{array}{c}0.0228 \\
(0.920)\end{array}$ & $\begin{array}{c}0.0005 \\
(0.100)\end{array}$ & $\begin{array}{c}-0.0147^{\star * \star} \\
(-3.050)\end{array}$ \\
\hline DIVYIELD & $\begin{array}{c}-0.0217^{\star \star \star} \\
(-28.470)\end{array}$ & $\begin{array}{c}-0.0031^{\star \star \star} \\
(-16.590)\end{array}$ & $\begin{array}{c}-0.0020 * \star \star \\
(-16.150)\end{array}$ & $\begin{array}{c}-0.0024^{\star \star \star} \\
(-13.680)\end{array}$ & $\begin{array}{c}-0.0124^{\star \star \star} \\
(-29.930)\end{array}$ & $\begin{array}{c}-0.0013^{\star \star \star} \\
(-17.510)\end{array}$ & $\begin{array}{c}-0.0004 \\
(-5.570)\end{array}$ \\
\hline S\&P 500 & $\begin{array}{c}0.0761^{\star \star \star} \\
(19.900)\end{array}$ & $\begin{array}{c}0.0397^{* * *} \\
(28.590)\end{array}$ & $\begin{array}{c}0.0021^{\star *} \\
(2.250)\end{array}$ & $\begin{array}{c}0.0081^{\star \star \star} \\
(8.330)\end{array}$ & $\begin{array}{c}0.00966^{\star \star \star} \\
(4.340)\end{array}$ & $\begin{array}{c}0.0189 * * * \\
(28.340)\end{array}$ & $\begin{array}{c}-0.0023^{\star * \star} \\
(-4.630)\end{array}$ \\
\hline $\begin{array}{l}\text { Industry dummies } \\
\text { Year dummies }\end{array}$ & $\begin{array}{l}\text { yes } \\
\text { yes }\end{array}$ & $\begin{array}{l}\text { yes } \\
\text { yes }\end{array}$ & $\begin{array}{l}\text { yes } \\
\text { yes }\end{array}$ & $\begin{array}{l}\text { yes } \\
\text { yes }\end{array}$ & $\begin{array}{l}\text { yes } \\
\text { yes }\end{array}$ & $\begin{array}{l}\text { yes } \\
\text { yes }\end{array}$ & $\begin{array}{l}\text { yes } \\
\text { yes }\end{array}$ \\
\hline Adj $R^{2}$ & 0.45 & 0.34 & 0.13 & 0.33 & 0.29 & 0.29 & 0.09 \\
\hline
\end{tabular}




\section{Table 8: Regressions of standardized ownership on standardized share characteristics}

The table reports results of OLS regressions, where the dependent variable is the institutional holdings of each institution type, respectively. Both the dependent variable and the independent variables are standardized as in Bennett, et al. (2003), and as described in equation (2). The variables are defined in Table III. T-statistics are given in parentheses, and statistical significance at $1 \%$ $\left(^{* \star \star}\right), 5 \%\left(^{\star \star}\right)$, and $10 \%\left({ }^{*}\right)$ levels is indicated with asterisks.

\begin{tabular}{|c|c|c|c|c|c|c|c|}
\hline & Aggregate & Bank & Insurance & Investment & IIA & Pension & Misc. \\
\hline Fx Exposure & $\begin{array}{c}0.1454^{\star \star \star} \\
(2.795)\end{array}$ & $\begin{array}{c}-0.2136^{\star \star} \\
(-2.350)\end{array}$ & $\begin{array}{c}0.1065^{\star \star} \\
(1.996)\end{array}$ & $\begin{array}{c}0.3041^{\star \star \star} \\
(3.463)\end{array}$ & $\begin{array}{c}0.2247^{\star \star \star} \\
(3.536)\end{array}$ & $\begin{array}{l}0.0469 \\
(0.743)\end{array}$ & $\begin{array}{c}0.0963^{\star \star} \\
(2.173)\end{array}$ \\
\hline SIZE & $\begin{array}{c}3.8628^{\star * \star} \\
(3.446)\end{array}$ & $\begin{array}{c}2.4443^{\star \star \star} \\
(3.446)\end{array}$ & $\begin{array}{c}2.1829^{* * *} \\
(3.560)\end{array}$ & $\begin{array}{c}2.4343^{\star \star \star *} \\
(3.192)\end{array}$ & $\begin{array}{c}2.5899 * * * \\
(3.495)\end{array}$ & $\begin{array}{c}2.3505^{\star \star \star} \\
(3.330)\end{array}$ & $\begin{array}{c}0.3887^{* * *} \\
(2.646)\end{array}$ \\
\hline $\log (b / m)$ & $\begin{array}{c}0.9525^{\star \star \star} \\
(3.245)\end{array}$ & $\begin{array}{c}0.4378^{\star \star \star} \\
(3.492)\end{array}$ & $\begin{array}{c}0.4725^{\star \star \star \star} \\
(3.123)\end{array}$ & $\begin{array}{c}0.3759 * \star \star \\
(2.988)\end{array}$ & $\begin{array}{c}0.8208^{\star \star *} \\
(3.041)\end{array}$ & $\begin{array}{c}0.4894^{\star \star *} \\
(3.347)\end{array}$ & $\begin{array}{c}0.3349^{* * *} \\
(3.234)\end{array}$ \\
\hline RET $_{-12,0}$ & $\begin{array}{c}-0.3982^{\star * *} \\
(-2.554)\end{array}$ & $\begin{array}{c}-0.4945^{* * *} \\
(-3.239)\end{array}$ & $\begin{array}{c}-0.2279^{\star} \\
(-1.944)\end{array}$ & $\begin{array}{c}-0.2047 \\
(-1.589)\end{array}$ & $\begin{array}{c}-0.0809 \\
(-0.802)\end{array}$ & $\begin{array}{c}-0.5685^{\star * *} \\
(-3.130)\end{array}$ & $\begin{array}{c}0.1497^{\star * *} \\
(2.942)\end{array}$ \\
\hline 1/Price & $\begin{array}{c}-0.6873^{\star * *} \\
(-2.699)\end{array}$ & $\begin{array}{c}-0.8329^{* * *} \\
(-3.224)\end{array}$ & $\begin{array}{c}0.1291^{\star * *} \\
(2.935)\end{array}$ & $\begin{array}{c}-0.3369^{\star *} \\
(-2.111)\end{array}$ & $\begin{array}{c}-0.4412^{* *} \\
(-2.412)\end{array}$ & $\begin{array}{l}0.0287 \\
(0.501)\end{array}$ & $\begin{array}{c}-0.2030^{\star *} \\
(-2.144)\end{array}$ \\
\hline DIVYIELD & $\begin{array}{c}-1.8114^{* * *} \\
(-3.269)\end{array}$ & $\begin{array}{c}-0.8173^{* * *} \\
(-3.085)\end{array}$ & $\begin{array}{c}-0.8046^{\star * *} \\
(-3.360)\end{array}$ & $\begin{array}{c}-1.1996 * * * \\
(-3.268)\end{array}$ & $\begin{array}{c}-1.5627^{\star \star *} \\
(-3.377)\end{array}$ & $\begin{array}{c}-0.6772^{\star * *} \\
(-2.551)\end{array}$ & $\begin{array}{c}-0.1468 \\
(-1.594)\end{array}$ \\
\hline S\&P 500 & $\begin{array}{c}1.0510^{* \star \star} \\
(3.399)\end{array}$ & $\begin{array}{c}1.7031^{* * *} \\
(3.856)\end{array}$ & $\begin{array}{c}0.2551^{\star * *} \\
(3.009)\end{array}$ & $\begin{array}{c}0.7058^{\star \star \star} \\
(3.332)\end{array}$ & $\begin{array}{l}0.0750 \\
(0.451)\end{array}$ & $\begin{array}{c}1.8824^{\star \star *} \\
(3.045)\end{array}$ & $\begin{array}{c}-0.1947^{\star \star} \\
(-2.397)\end{array}$ \\
\hline Industry dummies & yes & yes & yes & yes & yes & yes & yes \\
\hline Adj $R^{2}$ & 0.47 & 0.36 & 0.14 & 0.24 & 0.27 & 0.32 & 0.01 \\
\hline
\end{tabular}




\section{Table 9: Pooled OLS Regressions by time sub-samples}

The table reports OLS results, with the proportion of institutional holdings by each institution type indicated in respective columns. Each Panel includes a time-subsample indicated. The variables are defined in Table III. T-statistics robust for heteroskedasticity and autocorrelation are repoted in the parentheses, with the asterisks indicating statistical significance at one percent $\left({ }^{\star \star *}\right)$, five percent $\left({ }^{* *}\right)$, and ten percent $\left({ }^{*}\right)$ levels, respectively.

Panel A: $1983-1989$

\begin{tabular}{|c|c|c|c|c|c|c|c|}
\hline & Aggregate & Bank & Insurance & Investment & IIA & Pension & Misc. \\
\hline \multirow[t]{2}{*}{ Fx Exposure } & 0.0017 & $-0.0027^{\star \star \star}$ & $0.0007^{*}$ & $0.0007^{* \star \star}$ & $0.0025^{\star \star \star}$ & 0.0004 & 0.0002 \\
\hline & (1.297) & $(-4.015)$ & $(1.800)$ & $(2.776)$ & (3.325) & (1.275) & (0.838) \\
\hline \multirow[t]{2}{*}{ SIZE } & $0.0622^{\star \star \star}$ & 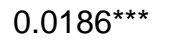 & $0.0095^{\star \star *}$ & $0.0049 * \star *$ & $0.0226^{\star \star \star}$ & $0.0058^{\star \star \star}$ & $0.0008^{\star \star *}$ \\
\hline & $(50.655)$ & (30.888) & (28.292) & (20.862) & (33.289) & (21.871) & (4.044) \\
\hline \multirow[t]{2}{*}{$\log (b / m)$} & $0.0218^{\star \star \star}$ & 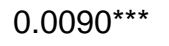 & $0.0027^{\star \star \star}$ & 0.0000 & $0.0070 * \star \star$ & $0.0029 * \star \star$ & 0.0002 \\
\hline & $(10.314)$ & $(8.700)$ & $(4.603)$ & $(0.035)$ & (5.946) & (6.479) & $(0.573)$ \\
\hline \multirow[t]{2}{*}{$\mathrm{RET}_{-12,0}$} & $-0.0004^{* * *}$ & $-0.0001^{\star \star \star}$ & $-0.0001^{* * *}$ & $-0.0001^{\star \star \star}$ & $-0.0001^{\star \star \star}$ & $-0.0001^{\star \star \star}$ & $0.0000^{\star \star}$ \\
\hline & $(-9.586)$ & $(-4.233)$ & $(-7.534)$ & $(-8.653)$ & $(-5.148)$ & $(-6.028)$ & $(2.215)$ \\
\hline \multirow[t]{2}{*}{ 1/Price } & $-0.5550^{\star * \star}$ & $-0.2752^{\star \star \star}$ & 0.0040 & $-0.0557^{\star \star \star *}$ & $-0.2033^{\star \star \star}$ & $-0.0168^{* *}$ & -0.0080 \\
\hline & $(-13.981)$ & $(-14.119)$ & $(0.366)$ & $(-7.354)$ & $(-9.250)$ & $(-1.962)$ & $(-1.282)$ \\
\hline \multirow[t]{2}{*}{ DIVYIELD } & $-0.0288^{\star * \star}$ & $-0.0062^{\star \star \star}$ & $-0.0032^{\star \star \star}$ & $-0.0029 * \star \star$ & $-0.0153^{\star * \star}$ & $-0.0008^{* \star *}$ & $-0.0005^{\star \star \star}$ \\
\hline & $(-28.689)$ & $(-12.478)$ & $(-11.485)$ & $(-15.337)$ & $(-27.489)$ & $(-3.618)$ & $(-3.183)$ \\
\hline \multirow[t]{2}{*}{ S\&P 500} & $0.0948 * * \star$ & $0.0374^{\star \star \star}$ & $0.0047^{\star \star \star}$ & $0.0064^{* \star *}$ & $0.0243^{\star \star \star}$ & $0.0239 * \star \star$ & $-0.0020 * \star \star$ \\
\hline & $(28.977)$ & $(23.310)$ & (5.206) & $(10.307)$ & $(13.424)$ & (33.957) & $(-3.818)$ \\
\hline \multirow{2}{*}{$\begin{array}{l}\text { Industry dummies } \\
\text { Year dummies }\end{array}$} & yes & yes & yes & yes & yes & yes & yes \\
\hline & yes & yes & yes & yes & yes & yes & yes \\
\hline \multirow[t]{2}{*}{ Adj $R^{2}$} & 0.46 & 0.29 & 0.12 & 0.12 & 0.30 & 0.24 & 0.00 \\
\hline & \multicolumn{7}{|c|}{ Panel B: 1990 - 1999} \\
\hline \multirow{3}{*}{ Fx Exposure } & Aggregate & Bank & Insurance & Investment & IIA & Pension & Misc. \\
\hline & $0.0045^{\star \star \star}$ & $-0.0020 * \star \star$ & 0.0001 & $0.0024^{\star \star \star}$ & $0.0042^{\star \star \star}$ & -0.0001 & 0.0000 \\
\hline & $(4.036)$ & $(-5.577)$ & $(0.194)$ & $(8.470)$ & $(6.008)$ & $(-0.738)$ & $(0.090)$ \\
\hline \multirow[t]{2}{*}{ SIZE } & $0.0814^{\star \star \star}$ & $0.0155^{\star \star \star}$ & $0.0124^{\star \star \star}$ & $0.0135^{\star \star \star}$ & $0.0331^{\star \star \star}$ & $0.0064^{\star \star \star}$ & $0.0006^{\star \star \star}$ \\
\hline & $(67.961)$ & $(39.160)$ & $(41.856)$ & $(44.493)$ & (43.999) & $(43.473)$ & $(4.186)$ \\
\hline \multirow[t]{2}{*}{$\log (b / m)$} & $0.0188^{\star \star \star}$ & $0.0041^{\star \star \star}$ & $0.0026^{\star \star \star}$ & $0.0027^{* \star *}$ & $0.0069 * \star \star$ & $0.0019 * * \star$ & $0.0007^{\star * *}$ \\
\hline & (8.508) & (5.539) & $(4.691)$ & $(4.761)$ & (4.999) & (7.034) & $(2.758)$ \\
\hline \multirow[t]{2}{*}{$\mathrm{RET}_{-12,0}$} & -0.0005 & $-0.0001^{\star \star \star}$ & $-0.0001^{\star \star \star}$ & $0.0000^{\star \star}$ & $-0.0002^{\star \star \star}$ & $-0.0001^{\star \star \star}$ & 0.0000 \\
\hline & $(-10.963)$ & $(-9.553)$ & $(-5.640)$ & $(-2.220)$ & $(-6.297)$ & $(-15.762)$ & $(0.292)$ \\
\hline \multirow[t]{2}{*}{ 1/Price } & $-0.2549 * * \star$ & $-0.2123^{\star \star \star}$ & $0.0346^{\star \star \star}$ & $-0.0219 * \star$ & $-0.0483^{\star}$ & $0.0108^{\star *}$ & $-0.0179 * \star \star *$ \\
\hline & $(-6.228)$ & $(-15.687)$ & (3.425) & $(-2.114)$ & $(-1.880)$ & $(2.157)$ & $(-3.838)$ \\
\hline \multirow[t]{2}{*}{ DIVYIELD } & $-0.0330^{\star \star \star}$ & $-0.0051^{\star \star \star}$ & $-0.0034^{\star * \star}$ & $-0.0050 * \star \star$ & $-0.0172^{\star \star \star}$ & $-0.0019 * \star \star$ & $-0.0004^{\star \star \star}$ \\
\hline & $(-45.066)$ & $(-20.968)$ & $(-18.992)$ & $(-27.139)$ & $(-37.456)$ & $(-21.000)$ & $(-4.375)$ \\
\hline \multirow[t]{2}{*}{ S\&P 500} & $0.1041^{\star \star \star}$ & $0.0428^{\star \star \star}$ & $-0.0001^{\star \star \star}$ & $0.0057^{\star \star \star}$ & $0.0313^{\star \star \star}$ & $0.0254^{\star \star \star}$ & $-0.0011^{\star \star}$ \\
\hline & (27.209) & (33.853) & $(-0.082)$ & $(5.872)$ & (13.050) & (54.195) & $(-2.452)$ \\
\hline \multirow{2}{*}{$\begin{array}{l}\text { Industry dummies } \\
\text { Year dummies }\end{array}$} & yes & yes & yes & yes & yes & yes & yes \\
\hline & yes & yes & yes & yes & yes & yes & yes \\
\hline Adj $R^{2}$ & 0.40 & 0.32 & 0.14 & 0.22 & 0.19 & 0.38 & 0.00 \\
\hline
\end{tabular}


Panel C: 2000 - 2007

\begin{tabular}{|c|c|c|c|c|c|c|c|}
\hline & Aggregate & Bank & Insurance & Investment & IIA & Pension & Misc. \\
\hline Fx Exposure & $\begin{array}{c}0.0110 \star \star \star \star \\
(7.136)\end{array}$ & $\begin{array}{l}-0.0003 \\
(-0.834)\end{array}$ & $\begin{array}{l}-0.0001 \\
(-0.450)\end{array}$ & $\begin{array}{c}0.0023^{\star * \star} \\
(6.197)\end{array}$ & $\begin{array}{c}0.0091^{\star * *} \\
(9.021)\end{array}$ & $\begin{array}{l}0.0002 \\
(1.531)\end{array}$ & $\begin{array}{c}-0.0002 \\
(-0.949)\end{array}$ \\
\hline SIZE & $\begin{array}{c}0.1118^{\star \star \star} \\
(76.738)\end{array}$ & $\begin{array}{c}0.0194^{\star \star *} \\
(53.373)\end{array}$ & $\begin{array}{c}0.0103^{\star \star \star} \\
(35.687)\end{array}$ & $\begin{array}{c}0.0220 * \star \star \\
(62.480)\end{array}$ & $\begin{array}{c}0.0508^{\star * *} \\
(53.184)\end{array}$ & $\begin{array}{c}0.0072^{\star \star \star} \\
(50.054)\end{array}$ & $\begin{array}{c}0.0022^{\star \star \star} \\
(11.176)\end{array}$ \\
\hline $\log (b / m)$ & $\begin{array}{c}0.0449 * * * \\
(14.317)\end{array}$ & $\begin{array}{c}0.0054^{\star \star \star} \\
(6.957)\end{array}$ & $\begin{array}{c}0.0074^{\star \star \star} \\
(11.900)\end{array}$ & $\begin{array}{c}0.0038^{\star \star \star} \\
(4.991)\end{array}$ & $\begin{array}{c}0.0230 * \star \star \\
(11.179)\end{array}$ & $\begin{array}{c}0.0014^{\star \star \star} \\
(4.654)\end{array}$ & $\begin{array}{c}0.0039 * \star \star \\
(9.367)\end{array}$ \\
\hline RET $_{-12,0}$ & $\begin{array}{c}-0.0004 \\
(-6.190)\end{array}$ & $\begin{array}{c}-0.0002^{\star \star \star} \\
(-12.826)\end{array}$ & $\begin{array}{l}0.0000 \\
(-0.839)\end{array}$ & $\begin{array}{c}-0.0001^{\star \star *} \\
(-4.880)\end{array}$ & $\begin{array}{c}-0.0001 \\
(-1.453)\end{array}$ & $\begin{array}{c}-0.0001^{\star \star \star} \\
(-8.693)\end{array}$ & $\begin{array}{l}0.0000 \\
(1.265)\end{array}$ \\
\hline 1/Price & $\begin{array}{c}0.3167^{\star \star \star} \\
(5.114)\end{array}$ & $\begin{array}{c}-0.0691^{\star \star \star} \\
(-4.478)\end{array}$ & $\begin{array}{r}-0.0107 \\
(-0.872)\end{array}$ & $\begin{array}{l}0.0940 * * \star \\
(6.288)\end{array}$ & $\begin{array}{c}0.3179 * \star \star \\
(7.834)\end{array}$ & $\begin{array}{c}0.0155^{\star \star \star} \\
(2.523)\end{array}$ & $\begin{array}{c}-0.0309 * * * \\
(-3.774)\end{array}$ \\
\hline DIVYIELD & $\begin{array}{c}-0.0212^{\star \star \star} \\
(-40.797)\end{array}$ & $\begin{array}{c}-0.00266^{\star \star \star} \\
(-20.294)\end{array}$ & $\begin{array}{c}-0.0016 * \star \star \\
(-15.267)\end{array}$ & $\begin{array}{c}-0.0035^{\star \star \star} \\
(-27.780)\end{array}$ & $\begin{array}{c}-0.0121^{\star \star \star} \\
(-35.677)\end{array}$ & $\begin{array}{c}-0.0009 * \star \star \\
(-17.320)\end{array}$ & $\begin{array}{c}-0.0005^{\star \star \star} \\
(-6.943)\end{array}$ \\
\hline S\&P 500 & $\begin{array}{c}0.0481^{\star \star \star} \\
(8.666)\end{array}$ & $\begin{array}{c}0.0406^{\star \star \star} \\
(29.316)\end{array}$ & $\begin{array}{l}0.0049 \star \star \star \star \\
(4.481)\end{array}$ & $\begin{array}{c}0.0269 * \star \star \\
(20.127)\end{array}$ & $\begin{array}{c}-0.0232^{\star * \star} \\
(-6.378)\end{array}$ & $\begin{array}{c}0.0024^{\star \star \star} \\
(4.286)\end{array}$ & $\begin{array}{c}-0.0035^{\star \star \star} \\
(-4.806)\end{array}$ \\
\hline $\begin{array}{l}\text { Industry dummies } \\
\text { Year dummies }\end{array}$ & $\begin{array}{l}\text { yes } \\
\text { yes }\end{array}$ & $\begin{array}{l}\text { yes } \\
\text { yes }\end{array}$ & $\begin{array}{l}\text { yes } \\
\text { yes }\end{array}$ & $\begin{array}{l}\text { yes } \\
\text { yes }\end{array}$ & $\begin{array}{l}\text { yes } \\
\text { yes }\end{array}$ & $\begin{array}{l}\text { yes } \\
\text { yes }\end{array}$ & $\begin{array}{l}\text { yes } \\
\text { yes }\end{array}$ \\
\hline $\operatorname{Adj} R^{2}$ & 0.44 & 0.43 & 0.14 & 0.40 & 0.22 & 0.26 & 0.09 \\
\hline
\end{tabular}




\section{Table 10: 3SLS Regressions of simultaneous equations}

The table reports 3SLS results, with the proportion of institutional holdings by each institution type indicated in respective columns. In Model 2, Inst. Ownership is the aggregate institutional ownership in the firm, foreign sales is the proportion of foreign sales for the firm, $R \& D$ expenses and Capital expenditures are R\&D expenses, and Capital expenditures, normalized by sales, respectively, ROA is net income divided by total assets, leverage is total debt, divided by total assets, and year trend takes on the value from 83 to 107 for years from 1983 to 2007. The rest of the variables are defined in Table III. T-statistics robust for heteroskedasticity and autocorrelation are repoted in the parentheses, with the asterisks indicating statistical significance at one percent $\left({ }^{\star * *}\right)$, five percent $\left({ }^{* \star}\right)$, and ten percent $\left({ }^{*}\right)$ levels, respectively.

Model 1: Dep. var. = Institutional ownership

\begin{tabular}{|c|c|c|c|c|c|c|c|}
\hline & $\mathrm{Agg}$ & Bank & $\operatorname{InS}$ & $\operatorname{Inve}$ & IIA & & \\
\hline Fx Exposure & $\begin{array}{c}0.0153^{\star \star \star} \\
(17.756)\end{array}$ & $\begin{array}{c}-0.0067^{\star \star \star} \\
(-23.594)\end{array}$ & $\begin{array}{l}0.0001 \\
(0.572)\end{array}$ & $\begin{array}{c}0.0076^{\star \star \star} \\
(35.124)\end{array}$ & $\begin{array}{c}0.0156 * \star \star \\
(28.567)\end{array}$ & $\begin{array}{c}-0.0007^{\star \star *} \\
(-6.265)\end{array}$ & $\begin{array}{c}-0.0006^{\star * *} \\
(-5.199)\end{array}$ \\
\hline SIZE & $\begin{array}{c}0.0919 \star \star \star \\
(115.400)\end{array}$ & $\begin{array}{c}0.0150 * \star \star \\
(57.730)\end{array}$ & $\begin{array}{c}0.0099 * \star \star \\
(55.022)\end{array}$ & $\begin{array}{c}0.0164^{\star \star \star} \\
(81.542)\end{array}$ & $\begin{array}{c}0.0424^{\star \star \star} \\
(84.117)\end{array}$ & $\begin{array}{c}0.0062^{\star \star \star} \\
(59.059)\end{array}$ & $\begin{array}{c}0.0019 \star \star \star \\
(17.722)\end{array}$ \\
\hline $\log (b / m)$ & $\begin{array}{c}0.0078^{\star \star \star} \\
(4.935)\end{array}$ & $\begin{array}{c}0.0062^{\star \star \star} \\
(11.994)\end{array}$ & $\begin{array}{c}0.0034^{\star \star \star} \\
(9.676)\end{array}$ & $\begin{array}{c}-0.0048^{\star \star \star} \\
(-11.984)\end{array}$ & $\begin{array}{c}-0.0005 \\
(-0.491)\end{array}$ & $\begin{array}{c}0.0029 * \star \star \\
(13.946)\end{array}$ & $\begin{array}{c}0.0005^{\star \star} \\
(2.268)\end{array}$ \\
\hline RET $_{-12,0}$ & $\begin{array}{c}-0.0005^{\star \star \star} \\
(-16.853)\end{array}$ & $\begin{array}{c}-0.0001^{* * *} \\
(-13.042)\end{array}$ & $\begin{array}{c}-0.0001^{\star * *} \\
(-7.244)\end{array}$ & $\begin{array}{c}-0.0001^{* * *} \\
(-11.349)\end{array}$ & $\begin{array}{c}-0.0002^{\star \star \star} \\
(-10.122)\end{array}$ & $\begin{array}{c}-0.0001^{* * *} \\
(-13.104)\end{array}$ & $\begin{array}{l}0.0000 \\
(0.798)\end{array}$ \\
\hline 1/Price & $\begin{array}{c}-0.0708^{\star \star} \\
(-2.326)\end{array}$ & $\begin{array}{c}-0.2361^{\star * *} \\
(-23.745)\end{array}$ & $\begin{array}{l}0.0047 \\
(0.683)\end{array}$ & $\begin{array}{c}0.0379 * \star \star \\
(4.941)\end{array}$ & $\begin{array}{c}0.1363^{\star \star \star} \\
(7.080)\end{array}$ & $\begin{array}{c}0.0063 \\
(1.573)\end{array}$ & $\begin{array}{c}-0.0191 * * * \\
(-4.659)\end{array}$ \\
\hline DIVYIELD & $\begin{array}{c}-0.0200 * \star * \\
(-53.027)\end{array}$ & $\begin{array}{c}-0.0032^{\star \star \star} \\
(-25.642)\end{array}$ & $\begin{array}{c}-0.0022^{* \star *} \\
(-25.611)\end{array}$ & $\begin{array}{c}-0.0019 * \star \star \\
(-19.641)\end{array}$ & $\begin{array}{c}-0.0112^{\star \star *} \\
(-46.980)\end{array}$ & $\begin{array}{c}-0.0014^{\star \star \star} \\
(-27.926)\end{array}$ & $\begin{array}{c}-0.0001^{\star \star} \\
(-1.974)\end{array}$ \\
\hline S\&P 500 & $\begin{array}{c}0.0507^{\star \star \star} \\
(19.818)\end{array}$ & $\begin{array}{c}0.0453^{\star \star \star} \\
(54.088)\end{array}$ & $\begin{array}{c}0.0047^{\star \star \star} \\
(8.149)\end{array}$ & $\begin{array}{c}-0.0016^{\star \star} \\
(-2.492)\end{array}$ & $\begin{array}{c}-0.0121^{\star * *} \\
(-7.437)\end{array}$ & $\begin{array}{c}0.0203^{\star \star *} \\
(59.698)\end{array}$ & $\begin{array}{c}-0.0060^{\star * *} \\
(-17.405)\end{array}$ \\
\hline ar tre & $\begin{array}{c}-0.0004^{\star * \star} \\
(-75.881)\end{array}$ & $\begin{array}{c}0.0000^{\star * *} \\
(-25.340)\end{array}$ & $\begin{array}{c}0.0000^{* * *} \\
(-38.980)\end{array}$ & $\begin{array}{c}-0.0001^{* * *} \\
(-64.037)\end{array}$ & $\begin{array}{c}-0.0002^{\star \star *} \\
(-56.221)\end{array}$ & $\begin{array}{c}0.0000^{* * *} \\
(-41.151)\end{array}$ & $\begin{array}{c}0.0000^{\star * *} \\
(-11.626)\end{array}$ \\
\hline \multicolumn{8}{|c|}{ Model 2: Dep. var. = FX exposure } \\
\hline Intercept & $\begin{array}{c}\text { Aggregate } \\
-32.1513^{\star} \\
(-26.242)\end{array}$ & $\begin{array}{c}\text { Bank } \\
-28.5903^{\star \star \star} \\
(-23.488)\end{array}$ & $\begin{array}{c}\text { Insurance } \\
-32.4129^{\star \star \star \star} \\
(-26.898)\end{array}$ & $\begin{array}{c}\text { Investment } \\
-27.6730^{\star \star *} \\
(-22.081)\end{array}$ & $\begin{array}{c}\text { IIA } \\
-29.7255^{\star \star \star} \\
(-23.688)\end{array}$ & $\begin{array}{r}\text { Pel } \\
-31.6 \\
(-26\end{array}$ & $\begin{array}{c}\text { Misc. } \\
-33.5166^{\star \star \star} \\
(-27.507)\end{array}$ \\
\hline Inst & $\begin{array}{c}0.2085^{\star * *} \\
(9.446)\end{array}$ & $\begin{array}{c}-1.7018^{* * *} \\
(-26.109)\end{array}$ & $\begin{array}{c}0.1259 \\
(1.313)\end{array}$ & $\begin{array}{c}2.5458^{\star \star \star} \\
(28.399)\end{array}$ & $\begin{array}{c}0.7237^{\star * *} \\
(20.220)\end{array}$ & $\begin{array}{c}-1.0048^{* * *} \\
(-6.227)\end{array}$ & $\begin{array}{c}-1.4675^{\star \star *} \\
(-8.983)\end{array}$ \\
\hline Size & $\begin{array}{c}-0.1038^{\star \star \star} \\
(-34.824)\end{array}$ & $\begin{array}{c}-0.0500^{\star * *} \\
(-17.265)\end{array}$ & $\begin{array}{c}-0.0882^{\star \star *} \\
(-33.299)\end{array}$ & $\begin{array}{c}-0.1194 * \star \star \\
(-43.891)\end{array}$ & $\begin{array}{c}-0.1060^{\star \star *} \\
(-40.170)\end{array}$ & $\begin{array}{c}-0.0795^{\star \star \star} \\
(-28.370)\end{array}$ & $\begin{array}{c}-0.0857^{\star \star \star} \\
(-33.899)\end{array}$ \\
\hline $\log (b / m)$ & $\begin{array}{c}-0.0926^{\star \star \star} \\
(-10.869)\end{array}$ & $\begin{array}{c}-0.0791^{\star * \star} \\
(-9.323)\end{array}$ & $\begin{array}{c}-0.0917^{\star \star \star} \\
(-10.792)\end{array}$ & $\begin{array}{c}-0.0847^{\star \star \star} \\
(-10.001)\end{array}$ & $\begin{array}{c}-0.0913^{\star \star \star} \\
(-10.741)\end{array}$ & $\begin{array}{c}-0.0869^{\star \star \star} \\
(-10.203)\end{array}$ & $\begin{array}{c}-0.0903^{\star \star \star} \\
(-10.639)\end{array}$ \\
\hline oreic & $\begin{array}{l}0.0001 \\
(0.028)\end{array}$ & $\begin{array}{c}-0.0081^{\star * \star} \\
(-2.540)\end{array}$ & $\begin{array}{c}-0.0012 \\
(-0.376)\end{array}$ & $\begin{array}{l}0.0021 \\
(0.655)\end{array}$ & $\begin{array}{c}0.0019 \\
(0.599)\end{array}$ & $\begin{array}{c}-0.0032 \\
(-0.988)\end{array}$ & $\begin{array}{c}-0.0009 \\
(-0.296)\end{array}$ \\
\hline R\&D & $\begin{array}{c}2.0924^{\star \star *} \\
(14.661)\end{array}$ & $\begin{array}{c}2.1061^{\star \star *} \\
(14.814)\end{array}$ & $\begin{array}{c}2.1044^{\star * *} \\
(14.753)\end{array}$ & $\begin{array}{c}2.0568^{\star \star \star} \\
(14.478)\end{array}$ & $\begin{array}{c}2.0482^{\star \star *} \\
(14.367)\end{array}$ & $\begin{array}{c}2.1352^{\star \star *} \\
(14.944)\end{array}$ & $\begin{array}{c}2.0886^{\star \star \star} \\
(14.646)\end{array}$ \\
\hline Cap.Exp. & $\begin{array}{c}1.3601^{\star \star *} \\
(18.978)\end{array}$ & $\begin{array}{c}1.3448^{\star \star \star} \\
(18.813)\end{array}$ & $\begin{array}{c}1.3752^{\star \star \star} \\
(19.172)\end{array}$ & $\begin{array}{c}1.3344^{\star \star \star} \\
(18.691)\end{array}$ & $\begin{array}{c}1.3472^{\star \star \star} \\
(18.837)\end{array}$ & $\begin{array}{c}1.3695^{\star \star \star} \\
(19.102)\end{array}$ & $\begin{array}{c}1.3611^{\star \star \star} \\
(18.988)\end{array}$ \\
\hline ROA & $\begin{array}{c}0.0135^{\star * *} \\
(2.576)\end{array}$ & $\begin{array}{c}0.0121^{\star *} \\
(2.333)\end{array}$ & $\begin{array}{c}0.0138^{\star * *} \\
(2.646)\end{array}$ & $\begin{array}{c}0.0087^{*} \\
(1.678)\end{array}$ & $\begin{array}{c}0.0096^{*} \\
(1.822)\end{array}$ & $\begin{array}{c}0.0142^{\star * *} \\
(2.734)\end{array}$ & $\begin{array}{c}0.0145^{\star \star *} \\
(2.788)\end{array}$ \\
\hline Leverage & $\begin{array}{c}-0.0145 \\
(-0.520)\end{array}$ & $\begin{array}{c}-0.0516^{*} \\
(-1.861)\end{array}$ & $\begin{array}{c}-0.0197 \\
(-0.708)\end{array}$ & $\begin{array}{r}-0.0357 \\
(-1.288)\end{array}$ & $\begin{array}{c}-0.0293 \\
(-1.052)\end{array}$ & $\begin{array}{c}-0.0164 \\
(-0.590)\end{array}$ & $\begin{array}{c}-0.0182 \\
(-0.655)\end{array}$ \\
\hline Year trend & $\begin{array}{c}0.0171^{\star \star \star} \\
(27.698)\end{array}$ & $\begin{array}{c}0.0151^{\star * \star} \\
(24.501)\end{array}$ & $\begin{array}{c}0.0172^{\star \star \star} \\
(28.207) \\
\end{array}$ & $\begin{array}{c}0.0149 * \star \star \\
(23.658)\end{array}$ & $\begin{array}{c}0.0159 * \star \star \\
(25.079) \\
\end{array}$ & $\begin{array}{c}0.0168^{\star \star \star} \\
(27.369) \\
\end{array}$ & $\begin{array}{c}0.0177^{\star \star \star} \\
(28.797) \\
\end{array}$ \\
\hline
\end{tabular}




\section{Table 11: Regressions by investment style}

The table reports OLS results, with the proportion of institutional holdings by each institutional investment style indicated in respective columns. The investment styles (dedicated, quasi-indexer, and transient) are defined in Bushee (1998), and data on them comes from Brian Bushee's website. The independent variables are defined in Table III. Panel A uses levels of variables, and Panel $B$ is based on first differences of both independent and dependent variables. T-statistics robust for heteroskedasticity and autocorrelation are repoted in the parentheses, with the asterisks indicating statistical significance at one percent $\left({ }^{\star \star}\right)$, five percent $\left({ }^{\star *}\right)$, and ten percent $(*)$ levels, respectively.

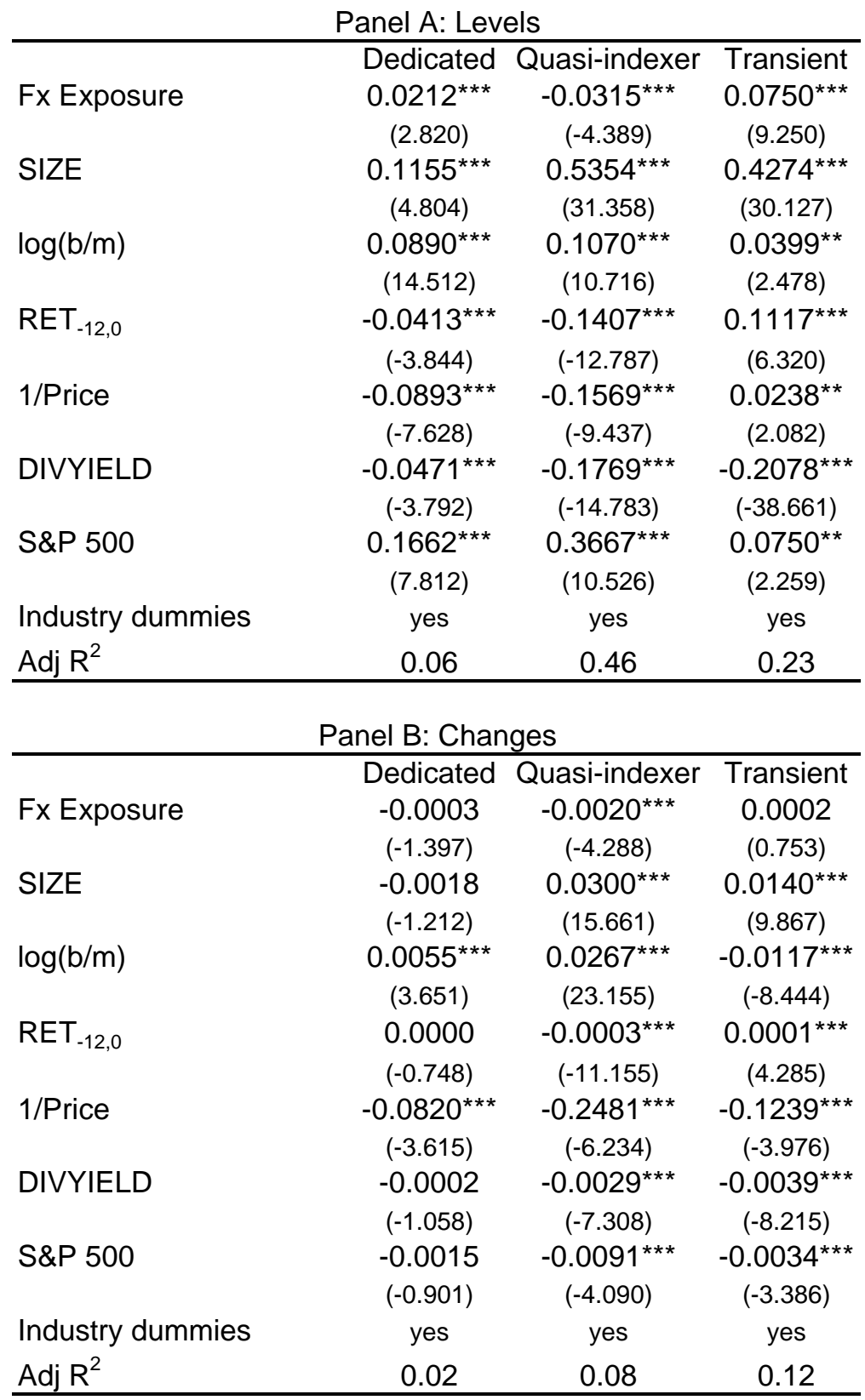

